\title{
Treatment of Diffuse Alveolar Hemorrhage: Controlling Inflammation and Obtaining Rapid and Effective Hemostasis
}

Jeong A. Park

Citation: Park, J.A. Treatment of Diffuse Alveolar Hemorrhage: Controlling Inflammation and Obtaining Rapid and Effective Hemostasis. Int. J. Mol. Sci. 2021, 22, 793. https://doi.org/10.3390/ ijms22020793

Received: 10 November 2020 Accepted: 11 January 2021 Published: 14 January 2021

Publisher's Note: MDPI stays neutral with regard to jurisdictional clai$\mathrm{ms}$ in published maps and institutional affiliations.

Copyright: () 2021 by the author. Licensee MDPI, Basel, Switzerland. This article is an open access article distributed under the terms and conditions of the Creative Commons Attribution (CC BY) license (https:// creativecommons.org/licenses/by/ $4.0 /)$.
Department of Pediatrics, Memorial Sloan Kettering Cancer Center, New York, NY 10065, USA; parkj2@mskcc.org or jeonga95@gmail.com; Tel.: +1-646-888-2320

\begin{abstract}
Diffuse alveolar hemorrhage (DAH) is a life-threatening pulmonary complication in patients with hematologic malignancies or systemic autoimmune disorders. Pathologic findings show pulmonary capillaritis, bland hemorrhage, diffuse alveolar damage, and hemosiderin-laden macrophages, but in the majority of cases, pathogenesis remains unclear. Despite the severity and high mortality, the current treatment options for DAH remain empirical. Systemic treatment to control inflammatory activity including high-dose corticosteroids, cyclophosphamide, and rituximab and supportive care have been applied, but largely unsuccessful in critical cases. Activated recombinant factor VII (FVIIa) can achieve rapid local hemostasis and has been administered either systemically or intrapulmonary for the treatment of DAH. However, there is no randomized controlled study to evaluate the efficacy and safety, and the use of FVIIa for DAH remains open to debate. This review discusses the pathogenesis, diverse etiologies causing DAH, diagnosis, and treatments focusing on hemostasis using FVIIa. In addition, the risks and benefits of the off-label use of FVIIa in pediatric patients will be discussed in detail.
\end{abstract}

Keywords: coagulopathy; corticosteroids; diffuse alveolar hemorrhage; hematopoietic stem cell transplantation; hemostasis; lung injury; pediatric; recombinant factor VIIa; rituximab; vasculitis

\section{Introduction}

Diffuse alveolar hemorrhage (DAH) is a clinical syndrome characterized by acute onset of alveolar infiltrates and hypoxemia which result in progressive diffuse alveolar bleeding, requiring immediate treatment [1]. Many systemic diseases can cause DAH, but the pathogenesis is not well understood in the majority of cases, and the standard treatment for DAH has not been established even for the systemic autoimmune disorders. The treatment includes supportive cares such as correction of hemodynamic instability or coagulopathy and ventilatory support, high-dose corticosteroids, immunosuppressants, and plasmapheresis. Though, the overall mortality still remains high. To control systemic inflammation, subsequent cytokine storm, and life-threatening bleeding, multidisciplinary treatment is required. Although the role of systemic immunosuppressive treatment has been emphasized, systemic immunosuppressive treatment alone is not enough to stop the life-threatening bleeding, and it takes times to work: these single-disciplinary approaches often lead to treatment failure.

Recombinant factor VIIa (FVIIa) was developed for the management of bleeding in hemophilic patients with inhibitors or in FVII-deficient patients. Despite this narrow indication, the off-label use of FVIIa has been increasing in non-hemophiliac patients to prevent or to treat uncontrolled bleeding in adults, children, neonates, and even preterm neonates [2,3]. The FVIIa has been reported to have a significant hemostatic effect in DAH as well [4-7]. However, there is no randomized controlled study to evaluate the efficacy in various conditions but also no consensus on the formulations, routes of administration, doses, and dosing regimens of FVIIa for the treatment of DAH. In addition, few studies have been reported in children. This review discusses the pathogenesis, pathologic findings, 
diagnosis and underlying etiologies of $\mathrm{DAH}$, treatment strategies, hemostatic treatments including FVIIa, and the off-label use of FVIIa for DAH in adult and pediatric patients.

\section{Pathogenesis of DAH}

The DAH syndrome is attributed to the injury to the lung microvasculature including the capillaries, arterioles, and venules lining the alveoli. DAH can be clinically categorized into 4 major groups: immune associated [ANCA-associated vasculitis (AAV) and connective tissue disease], congestive heart failure associated, miscellaneous [infection, trauma, clotting disorder, drugs, malignancy, and hematopoietic stem cell transplantation (HCT)], and idiopathic. The major pathologic findings of DAH include antibody-mediated pulmonary capillaritis, bland alveolar hemorrhage, and diffuse alveolar damage [8-10]. Pulmonary capillaritis is the most common pattern and is defined by neutrophilic infiltration of the perivascular interstitium (alveolar septae) of the capillaries, endothelial edema, injury, and fibrinoid necrosis $[9,11,12]$. It is associated with systemic vasculitides, connective tissue disorders, immune complex mediated disorders, and post-transplant hemorrhages, and systemic immunosuppressive treatment is effective to control DAH [12]. Hemosiderin-laden macrophage accumulation is characteristic in $24-48$ hours after the initial vessel injury $[8,13]$. Bland alveolar hemorrhage is not directly linked with inflammation or destruction of the alveolar capillaries, venules, and arterioles but with widespread leaking of red blood cells (RBCs) into the alveoli $[8,10]$. It is observed in drug-induced DAH, systemic lupus erythematosus (SLE), disseminated intravascular coagulation (DIC), cardiac originated DAH (mitral stenosis or mitral regurgitation), and infections such as HIV or infective endocarditis $[8,9]$. Generally, systemic immunosuppressants are not indicated except in cases of systemic autoimmune disease. Diffuse alveolar damage, the primary lesion in acute respiratory distress syndrome (ARDS), is characterized by interstitial and intra-alveolar edema, capillary congestion, microthrombi, epithelial necrosis and sloughing, the presence of fibrinous exudates in alveolar air spaces, and hyaline membrane formation [14]. It is associated with ARDS, cytotoxic drugs, radiation treatment, SLE, and cocaine inhalation $[15,16]$.

Systemic inflammation involving pulmonary vasculature triggered by overactive autoimmune response and cytokine storm deemed to be the primary cause of DAH. Macrophage activation and high ferritin and IL-6 levels have been implicated in the pathogenesis of acute lung injury, inflammation, and pulmonary hemorrhage [17]. Pulmonary capillaritis-associated DAH bears on fibrin thrombi occluding the intra-alveolar capillaries and fibrinoid necrosis of the small blood vessels. It is often accompanied by inflammation of large blood vessels, IgG/C3 deposition in the alveolar walls, and erythrocytes extravasation into the alveolar spaces [18]. In animal models, DAH is mediated by opsonin-dependent uptake of dead cells by natural IgM and subsequent activation of the early classical complement pathway [19]. During inflammation, bone marrow-derived macrophages are recruited to the alveoli and differentiate into proinflammatory (M1-like) macrophages [20], and the IgM/C3-opsonized dead cells engage CR3/CR4 (a component of C3b receptor 3 and 4) on macrophages, expediting the development of DAH [19]. Neutrophil extracellular traps (NETs), fibrous networks which protrude from the membranes of activated neutrophils, also have a detrimental role in both autoimmune disorders and acute lung injury [21]. NETs accelerate the inflammatory processes by releasing a wide range of active molecules like danger-associated molecular patterns (DAMPs), histones, active lytic-enzymes, and multiple cytokines in the extracellular space [22]. Imbalance between NETs formation and degradation exacerbates immune responses and tissue injury [23], and prolonged exposure to NETs-related cascades increases systemic organ damage [24]. NETs are closely associated with development of DAH in murine autoimmune disease models, and targeting NETs with DNase-I reduced severity of DAH lesions and improved survival $[25,26]$.

DAH after HCT is also closely associated with lung injury and subsequent vasculopathy. High-dose chemotherapy, thoracic or total body irradiation, and undocumented 
infections have been implicated as the initial injury to the lung leading to post-transplant DAH [27]. Animal models suggest that alveolitis develops during the acute phase of graft-versus-host disease (GVHD), and it is characterized by alveolar hemorrhage, increase in the alveolar leukocytes, platelet microthrombi, damage of alveolar endothelial and epithelial cells, increased turnover rate of alveolar cells, and increased cell counts and protein concentration of the bronchoalveolar lavage (BAL) fluid [28,29]. Irrespective of post-transplant leukopenia, neutrophils and neutrophil products are detected in the lower respiratory tract of HCT recipient at the time of DAH [30]. Besides, vasculitis of small muscular arteries and thrombotic microangiopathy in the form of endothelial swelling and thrombi are frequently observed in acute hemorrhagic pulmonary edema after transplantation $[9,31]$. The vasculopathy manifests as concentric intimal or medial hyperplasia with luminal narrowing, prominent myxoid changes, extravasated RBCs, and the presence of foamy histiocytes apart from thrombotic microangiopathy [31-33]. Add on, hematopoietic growth factors (G-CSF) and cytokine storms make worse the alveolar damage and capillary leakage by increasing neutrophil infiltration into the lungs [30]. Dysregulated cytokine release including both TH1 (IL-2, IL-6, IFN- $\gamma$, and TNF- $\alpha$ ) and TH2 (IL-9 and IL-15) cytokines further potentiates the inflammatory response [34].

\section{Diagnosis of DAH}

The differential diagnosis of DAH is broad, and the etiologies of DAH can be broadly divided into immune- and non-immune-mediated causes (Table 1) [35]. A careful history, physical examination, and laboratory tests can often help to establish the risk factors and most likely etiology of the alveolar hemorrhage. Bronchoscopy is the key investigation needed to diagnose DAH by lavage and to exclude other associated infections. Bronchoscopy has higher yield if performed within the first $48 \mathrm{~h}$. Persistent or increasing blood on three sequential lavage aliquots from one affected area of lung supports the diagnosis of DAH [36]. The number of hemosiderin-laden macrophages should be counted in cases of subacute or recurrent DAH $[8,16]$. The finding of $\geq 20 \%$ hemosiderin-laden macrophages in BAL fluid is commonly regarded as diagnostic of DAH and closely associated with severity [36-38]. BAL specimens should be sent for routine bacterial, mycobacterial, fungal, and viral cultures, and Pneumocystis stains to exclude infections. The role of transbronchial lung biopsy is not established in the diagnosis of DAH as the area of involvement is often patchy [8], but in any patients presenting with DAH of unclear causes a lung biopsy is strongly recommended to determine the underlying etiologies $[10,39,40]$. Imaging studies including chest radiographies and high-resolution chest computed tomography (CT) scans provide additional information to support a diagnosis of DAH. Typical pattern of DAH includes focal or diffuse areas of ground glass opacities or consolidations as a consequence of alveolar filling. Laboratory tests include a complete blood count with differential; coagulation studies; serum BUN and creatinine analysis; ANCA testing (c-ANCA and p-ANCA); antigen-specific ELISA [proteinase 3(PR3) and myeloperoxidase (MPO)], analysis of anti-phospholipid antibodies (APL), lupus anticoagulant, anti-cardiolipin (CL) antibodies, anti- $\beta-2$ glycoprotein 1 ( $\beta 2 \mathrm{GP}$ ) antibodies, anti-glomerular basement membrane (GBM) antibodies, anti-nuclear antibodies (ANA), and rheumatoid factor (RF); urinalysis with urine sediment assessment; and a urine drug screen $[9,41]$. 
Table 1. Etiologies of diffuse alveolar hemorrhage and treatment options.

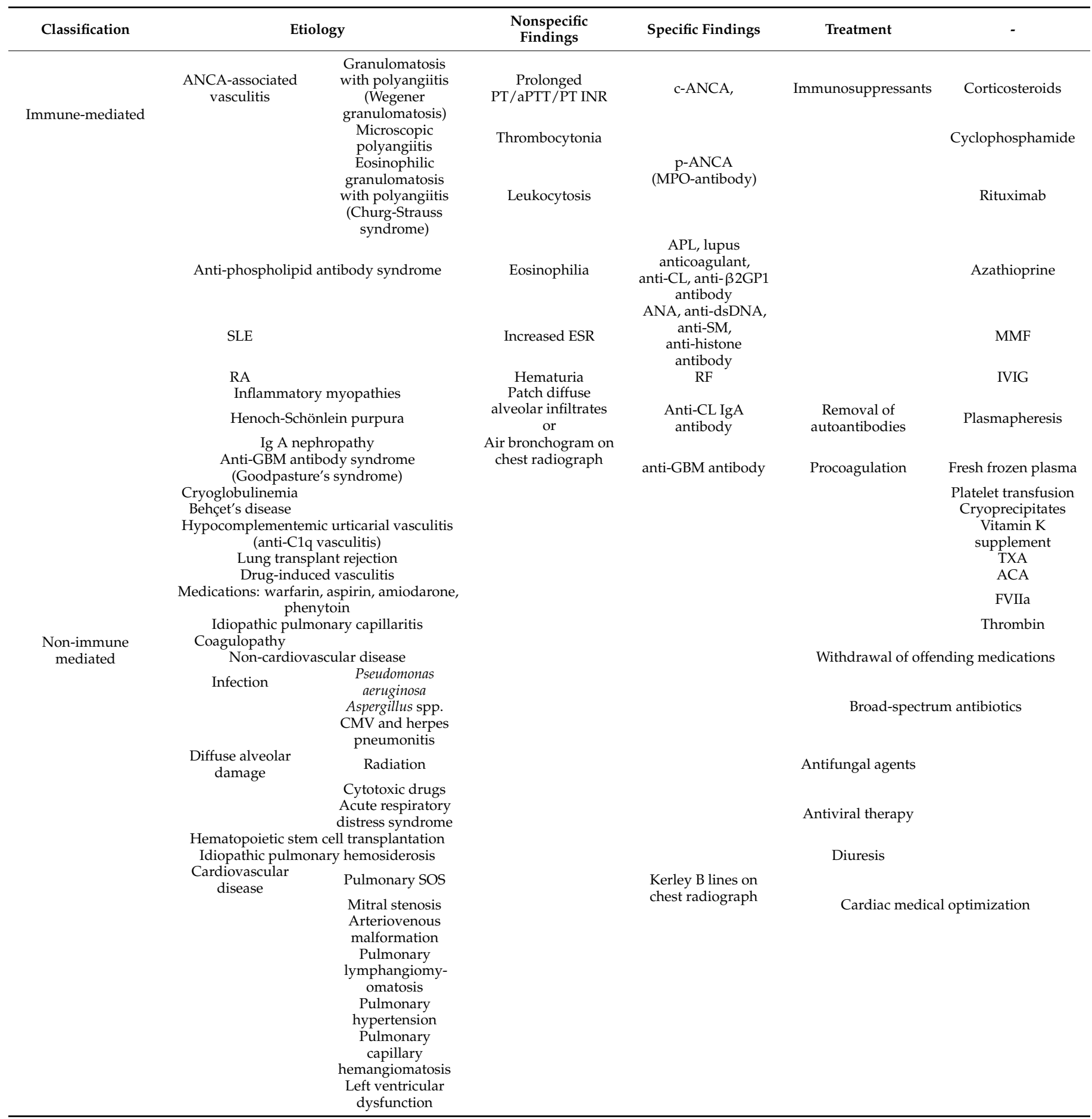

Abbreviations: ANA, anti-nuclear antibody; ANCA, anti-neutrophil cytoplasmic antibody; anti- $\beta 2 \mathrm{GPA}$, anti- $\beta$-2 glycoprotein 1 antibody; anti-CL antibody, anti-cardiolipin antibody; anti-dsDNA antibody, anti-double stranded DNA antibody; anti-MPO, anti-myeloperoxidase antibody; APL, anti-phospholipid antibody; anti-SM antibody; anti-smooth muscle antibody; C1q, complement 1q; c-ANCA, cytoplasmicANCA; CMV, cytomegalovirus; EACA, epsilon aminocaproic acid; ESR, erythrocyte sediment rate; FFP, fresh frozen plasma; GBM, glomerular basement membrane; INR, international normalized ratio; IPH, idiopathic pulmonary hemosiderosis; IVIG, intravenous immunoglobulin; MMF, mycophenolate mofetil; p-ANCA, perinuclear-ANCA; PT, prothrombin time; aPTT, a partial thromboplastin time; RA, rheumatoid arthritis; RF, rheumatoid factor; FVIIa, activated recombinant factor VII; SLE, systemic lupus erythematosus; SOS, sinusoidal obstruction syndrome; TXA, tranexamic acid. 


\section{Treatment of DAH}

DAH, especially acute macroscopic hemorrhage, has a high mortality rate, requiring prompt and aggressive multidisciplinary management. Treatment for DAH involves three major disciplines: (1) supportive care including hemodynamic correction, transfusion, and ventilator support, ranging from oxygen supplementation to mechanical ventilation with high positive end-expiratory pressure (PEEP) producing a tamponade effect to limit capillary bleeding; (2) treatment of underlying disease including intensive immunosuppressive treatments to control disease activity, plasmapheresis to remove autoantibodies, and antivirals or antibiotics for infection-associated pulmonary hemorrhages; and (3) rapid and effective local hemostasis [7].

The most immediate life-threatening complication of DAH is acute hypoxemic respiratory failure. When severe DAH results in ARDS, high levels of $\mathrm{FiO}_{2}$ and PEEP are often needed to achieve acceptable oxygenation. Although there is no consensus on ideal PEEP levels for DAH and it should be adjusted by the severity of respiratory failure and lung recruitability, DAH has been managed with high PEEP and permissive hypercapnia to reduce the active bleeding and prevent lung collapse [42]. The PEEP used in severe ARDS lies around $8.5 \mathrm{~cm} \mathrm{H}_{2} \mathrm{O}$ [43], but the PEEP level should be selected by carefully considering oxygenation advantage and the putative benefits on lung protection [44].

To control the inflammatory activity, high-dose corticosteroids are recommended to start promptly, along with treatment for underlying disease. Corticosteroids have been accepted as a mainstay of treatment aimed at reducing acute inflammatory responses such as lung alveolar epithelial swelling, thrombotic microangiopathy, and increased inflammatory cells and cytokines $[10,40,45]$. Based on anecdotal reports and retrospective studies, systemic high-dose corticosteroids (500 mg to $2 \mathrm{~g} /$ day or $30 \mathrm{mg} / \mathrm{kg} /$ day of intravenous (iv) methylprednisolone for 3-5 days followed by gradual tapering over 4 weeks) are recommended to treat DAH $[4,40,46,47]$. However, steroid treatment alone is not sufficient to stop acute macroscopic pulmonary bleeding and is often fatal if the etiology is infectious or if the patient is in an immunocompromised status; the benefit of high-dose corticosteroids in critically ill patients remains undefined. Despite the widespread use of high-dose corticosteroids for DAH, the mortality exceeds $50 \%$, especially in patients requiring intensive care unit (ICU) admission or in patients received HCT [48]. For the treatment of $\mathrm{AAV}$, reduced-dose glucocorticoids had comparable efficacy to standard-dose corticosteroids with respect to mortality or incidence of end-stage renal disease (ESRD) but also reduced the incidence of serious infections at 1 year [49]. A study investigating the dose effect of corticosteroids for DAH suggested that patients treated with low-dose methylprednisolone ( $<250 \mathrm{mg}$ /day) had a significantly lower ICU mortality rate compared to the patients treated with medium-dose (250-1000 mg/day) or high-dose ( $>1000 \mathrm{mg} /$ day) methylprednisolone, and overall mortality did not differ by the doses of corticosteroids, raising questions about the validity of high-dose corticosteroids for DAH [48].

To eliminate autoreactive antibodies or triggering factors rapidly, plasmapheresis has been used as an adjunctive therapy particularly in autoimmune connective disorders, such as anti-GBM disease, AAV or SLE-associated pulmonary capillaritis. Plasmapheresis is performed daily or on alternating days for 14 days. Each exchange involves 1-1.5 times the total plasma volume and is replaced with albumin or FFP. Although retrospective studies reported excellent patient outcome and safety [50], long-term follow-up data or matched analyses to compare the efficacy of plasmapheresis to methylprednisolone have failed to show significant benefit [51-53]. The evidence-based guidelines of the American Society for Apheresis recommend using plasmapheresis in AAV patients with DAH presenting with hypoxemic respiratory failure requiring either high-flow supplemental oxygen or mechanical ventilation [54]. Recently released data of randomized controlled trial of plasma exchange and glucocorticoids for treatment of AAV (NCT00987389) suggested that the use of plasmapheresis did not reduce the mortality or the incidence of ESRD [49].

Rituximab, a chimeric monoclonal antibody targeting CD20, has been used as another viable alternative. Antibody-mediated modification and/or depletion of ANCA producing 
CD20(+) plasma cells is a proposed mechanism for rituximab to decrease autoantibody production and to control disease activity $[55,56]$. Although most of the studies have been limited, they suggest that rituximab is an effective therapeutic option for DAH in connective tissue disease or autoimmune disorders. Rituximab on a compassionate use basis for patients with refractory AAV reported successful treatment outcomes [57-60]. These encouraging results led to randomized controlled trials evaluating the effect of rituximab as a remission induction therapy in patients with severe AAV (NCT00104299, NCT01731561). Comparison between rituximab and cyclophosphamide pulse therapy for AAV showed a similar efficacy [61]. A randomized trial comparing the effect of combination therapies of glucocorticoids plus rituximab $\left(375 \mathrm{mg} / \mathrm{m}^{2}\right.$ once weekly for 4 weeks) and glucocorticoids plus cyclophosphamide ( $2 \mathrm{mg} / \mathrm{kg} /$ day) also demonstrated comparable efficacy of rituximab for the remission induction in severe $\mathrm{AAV}$, and rituximab showed a better effectiveness for recurrent disease, major renal disease, or alveolar hemorrhage [58]. For long-term remission, rituximab was compared to azathioprine maintenance (NCT00748644), and rituximab treatment showed significantly longer remission duration and improved overall survival [61].

For obtaining rapid hemostasis, coagulopathy should be closely monitored and quickly corrected. Commonly accepted targets are platelet counts more than $50,000 / \mu \mathrm{L}$ and a prothrombin time-international normalized ratio (PT-INR) less than 1.5. Depending on the causes, platelet transfusions, vitamin K supplementation, cryoprecipitates, and fresh frozen plasma should be supplemented. Besides, in order to stop the bleeding, various prothrombotic treatments including antifibrinolytics, particularly lysine analogues tranexamic acid (TXA) and epsilon aminocaproic acid (EACA), thrombin, and FVIIa have been used for DAH and reported with a variety of success rates. Mechanisms of the hemostatic agents are described in Figure 1.

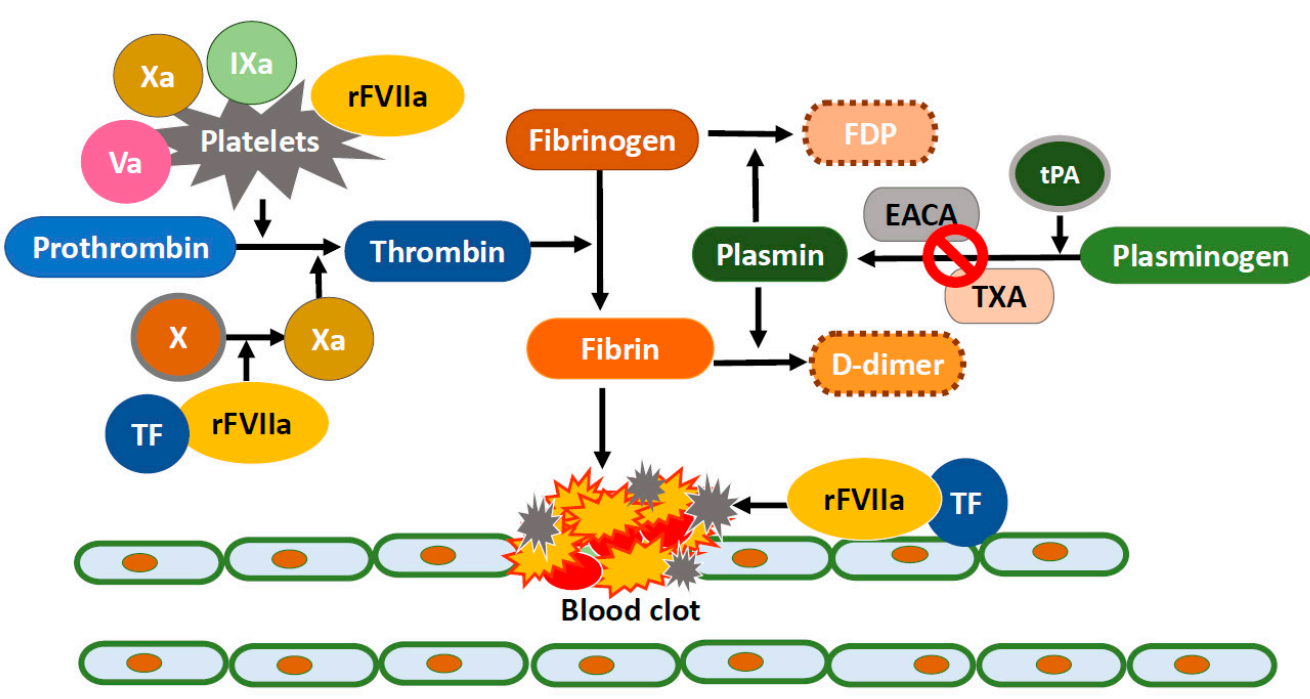

Figure 1. Coagulation and fibrinolytic cascades and the mechanisms of hemostatic agents.

TXA prohibits conversion of plasminogen into plasmin inhibiting fibrinolysis and stabilizes blood clots [62]. In addition to intravenous use, intrapulmonary or aerosolized TXA has been used for DAH [63-65]. Nebulized TXA led to complete or near cessation of bleeding in 10/18 pediatric patients with DAH [65], and recently, Neil et al. published a successful treatment outcome in 19 pediatric patients with DAH: 18 out of 19 patients had stopped bleeding after TXA inhalation [64]. However, TXA therapy failed to show significant effect on reducing bleeding-associated mortality in patients with hematologic malignancies [66] but also increased risk of post-operative seizures [67] and showed limited efficacy on profound and recurrent bleedings [65]. EACA, another option for hemostatic treatment, is a lysine analog that binds competitively to plasminogen, blocking plasminogen from binding to fibrin and the subsequent conversion to plasmin, resulting in the 
inhibition of fibrin degradation (fibrinolysis) [68]. EACA has been used in addition to corticosteroids in patients with post-transplant DAH and reported to reduce 100-day mortality rate from $83 \%$ to $44 \%$ in patients treated with corticosteroids [69]. Though, a recent follow-up study reported that adjuvant treatment with EACA did not yield a significant difference in the outcomes of patients with DAH after HCT. The overall mortality on day 100 was still high at $85 \%$ [48].

In addition, the effects of thrombin or fibrinogen-thrombin for treatment of severe hemoptysis have also been reported [70,71]. Recently, Lee et al. published the efficacy of intrapulmonary thrombin treatment for DAH in patients with hematologic malignancies. Intrapulmonary thrombin stopped bleedings rapidly in 13 of 15 patients' refractory to corticosteroids with TXA treatment and significantly improved oxygenation status without thromboembolic complications [72]. Thrombin production is the final coagulation step required to convert fibrinogen to fibrin which produces a hemostatic lattice for platelet aggregation and thrombus formation at the site of injury [73]. Besides the coagulation cascade, thrombin causes vasoconstriction at the smooth muscle cell level and promotes platelet aggregation at the site of the thrombus [74].

\section{Recombinant FVIIa Treatment for DAH}

Recombinant FVIIa (FVIIa) is also used as an alternative 'broad spectrum hemostatic agent' to enhance hemostasis in patients with life-threatening intractable bleeding. Given that tissue factor (TF) pathway inhibitors (TFPI) increased in inflamed alveoli and these TFPIs prevent FVIIa-TF formation and FX activation, the inflamed lungs are more susceptible to bleeding [75]. FVIIa can overcome the effect of TFPI and restore thrombin generation. It promotes hemostasis via both a TF-dependent pathway at the sites of endothelial injury and a TF-independent pathway which directly activate factors IX and X on the surface of activated platelets in the absence of TF (Figure 1). Factor X converts prothrombin to thrombin, which in turn converts fibrinogen to fibrin. Alveolar TF remains high in inflammatory pulmonary conditions, including DAH, acute respiratory distress syndrome (ARDS), and pneumonia, as well as after lipopolysaccharide local challenge in the alveoli [5,76-78]. Alveolar TF-FVIIa complex activates coagulation factors IX and X, which in turn initiates a cascade of reactions, leading to thrombin burst and fibrin formation at the site of injury [5]. However, due to the separation between the alveolar and systemic compartments of the lung, FVIIa, similarly to most biologics, requires a high systemic concentration to affect specific receptors in the alveolar compartment. This requires higher and repeated doses of intravenous FVIIa, associated with a higher risk of thromboembolic complications $[7,79,80]$. On the other hand, intrapulmonary locally administered FVIIa has been reported to have successful outcomes with a relatively small dose $(50 \mu \mathrm{g} / \mathrm{kg})$ and less frequent administration $[5,81,82]$. Intrapulmonary (ip) administration can ensure that FVIIa reaches its alveolar receptor, TF, and it decreases systemic adverse effects because the alveolocapillary membrane does not allow the transmembranous passage of FVIIa. Pulmonary-administered FVIIa combines with TF and forms TF-FVIIa complex which activates coagulation factor IX and X, inducing balanced hemostasis. With relatively small doses, FVIIa results in both durable hemostasis and a significant improvement in oxygen transport capacity [7]. Moreover, TFPIs produced by alveolar macrophages are highly expressed in the airspace in inflammatory conditions secondary to acute lung injury and contribute to the balanced hemostasis without the theoretical risk of intra-alveolar thrombotic complications with intrapulmonary FVIIa $[7,83,84]$. Accordingly, treatment with FVIIa has a potentially high benefit-to-risk ratio in DAH when administered via the local intrapulmonary route.

Case reports and clinical studies have reported the effectiveness of FVIIa in various conditions, including thrombocytopenia, functional platelet defects, hemorrhagic complications after HCT (e.g., DAH and hemorrhagic cystitis), gunshot wounds, and coagulopathy of liver failure [85-92]. However, the efficacy and side effects of FVIIa in non-hemophiliac settings are largely anecdotal, and many questions still remain regarding the appropriate 
indications and guidelines for use, risks of thrombotic complications, monitoring, dosing, and integration with transfusion therapy. A Cochrane review of the off-label use of FVIIa reported that FVIIa did not have a significant mortality benefit over placebo but showed a trend toward control of bleeding, a lower number of transfusions, and arterial thromboembolic events [93].

There is growing literature supporting the use of FVIIa to stop acute pulmonary hemorrhage following various diseases and injuries, including pneumonia, HCT, metastatic cancer, idiopathic pulmonary hemosiderosis (IPH), and immune-associated vasculitis. Due to lack of randomized controlled studies, FVIIa has been used as a final effort to stop the bleeding, and many studies have reported the successful use of FVIIa for lifethreatening DAH $[5,81,82,94,95]$. Although the optimal dose and dosing intervals remain to be determined, systemic administration usually entails the intravenous administration of 35-200 $\mu \mathrm{g} / \mathrm{kg}$ as either a single dose or repeated doses every $2-4 \mathrm{~h}[4,6,95,96]$, and intrapulmonary therapy typically involves bronchoscopy with a total dose of $50-90 \mu \mathrm{g} / \mathrm{kg}$ of FVIIa diluted in normal saline as either a single dose or, if bleeding continues, as repeated doses over $24 \mathrm{~h}[7,81,97,98]$. The FVIIa treatment for pulmonary hemorrhage in adults is listed in Table 2. Twenty-nine in 111 cases were related to immune disorders, and the remaining 82 cases were non-immune-related DAH where hematopoietic stem cell transplant (HCT)-related DAH showed a majority ( $75 \%, 62$ cases). While the mortality of immune-mediated DAH was $25 \%$ (7 in 28 patients), that of non-immune-mediated DAH showed a higher mortality rate, $47 \%$ (27 in 58 patients: the outcome for the other 24 patients was not specified). Although the mean dose of FVIIa for iv injection was $427 \mu \mathrm{g} / \mathrm{kg} /$ episode for immune-related DAH and $167 \mu \mathrm{g} / \mathrm{kg} /$ episode for non-immunerelated $\mathrm{DAH}$, most of the fatality cases were not directly related to $\mathrm{DAH}$, and the complete response rate was similar in both groups; 19 in 21 patients and 23 in 23 patients. For iv use, approximately $250 \mu \mathrm{g} / \mathrm{kg} /$ episode of FVIIa was administered, while, $50 \mu \mathrm{g} / \mathrm{kg} /$ episode of FVIIa was used for ip administration. The response rate did not differ by the administration route or administered dose: 42 in 44 patients with iv FVIIa and 19 in 21 patients with ip FVIIa showed complete response.

Table 2. Published data on recombinant factor VIIa treatment for diffuse alveolar hemorrhage in adults.

\begin{tabular}{|c|c|c|c|c|c|c|c|c|c|}
\hline References & Year & $\begin{array}{l}\text { Patients } \\
\text { (Sex/Age) }\end{array}$ & Previous History & Route & Dose of FVIIa & $\begin{array}{l}\text { Additional } \\
\text { Therapies }\end{array}$ & Outcome & $\begin{array}{c}\text { TE } \\
\text { Complication }\end{array}$ & $\begin{array}{c}\text { Case of } \\
\text { Death }\end{array}$ \\
\hline \multirow{3}{*}{$\begin{array}{l}\text { Henke et al. } \\
{[6]}\end{array}$} & \multirow{3}{*}{2004} & & & & Immune related & & & & \\
\hline & & $\mathrm{M} / 53$ & $\begin{array}{c}\text { ANCA-vasculitis } \\
(n=2), \text { viral } \\
\text { infection } \\
\text { SLE APS }\end{array}$ & IV & $120 \mu \mathrm{g} / \mathrm{kg} \times 3$ doses & $\begin{array}{l}\mathrm{CS}, \mathrm{CPM}, \mathrm{MMF} \text {, } \\
\text { plasmapheresis }\end{array}$ & CR & none & 0 \\
\hline & & $\mathrm{M} / 25$ & $\begin{array}{c}\text { SLE, APS, } \\
\text { nephritis, pleural } \\
\text { effusion }\end{array}$ & IV & $90 \mu \mathrm{g} / \mathrm{kg} \times 3$ doses & CS & CR & none & 0 \\
\hline \multirow{2}{*}{$\begin{array}{c}\text { Heslet et al. } \\
\text { [5]. }\end{array}$} & \multirow[t]{2}{*}{2006} & $\mathrm{M} / 63$ & $\begin{array}{l}\text { Sarcoidosis, } \\
\text { septic shock } \\
\text { Wegener's }\end{array}$ & IP & $50 \mu \mathrm{g} / \mathrm{kg} \times 1$ dose & $\begin{array}{l}\text { TXA, aprotinin, } \\
\text { desmopressin }\end{array}$ & CR & none & 1 \\
\hline & & $\mathrm{F} / 34$ & $\begin{array}{c}\text { granulomatosis, } \\
\text { Churg-Strauss } \\
\text { vasculitis }\end{array}$ & IP & $50 \mu \mathrm{g} / \mathrm{kg} \times 1$ doses & TXA, aprotinin & CR & none & 0 \\
\hline $\begin{array}{c}\text { Dabar et al. } \\
\text { [97] }\end{array}$ & 2011 & NA & ANCA-vasculitis & NA & $90 \mu \mathrm{g} / \mathrm{kg} \times 1$ dose & none & CR & none & 0 \\
\hline $\begin{array}{l}\text { Mandal et al. } \\
\text { [99] }\end{array}$ & 2012 & $\mathrm{~F} / 23$ & $\begin{array}{c}\text { Microscopic } \\
\text { polyangitis } \\
\text { (pulmonary renal } \\
\text { vasculitis), } \\
\text { necrotizing } \\
\text { glomerulonephri- } \\
\text { tis }\end{array}$ & IV & $90 \mu \mathrm{g} / \mathrm{kg} \times 2$ doses & $\begin{array}{c}\text { MMF, } \\
\text { plasmaphersis }\end{array}$ & CR & none & 0 \\
\hline $\begin{array}{c}\text { Esper et al. } \\
\text { [82] }\end{array}$ & 2014 & $\mathrm{~F} / 37$ & $\begin{array}{c}\text { SLE, Sjögren } \\
\text { syndrome }\end{array}$ & IP & $50 \mu \mathrm{g} / \mathrm{kg} \times 1 \mathrm{dose}$ & CS, RTX & $\mathrm{CR}$ & none & 0 \\
\hline $\begin{array}{l}\text { Alabed et al. } \\
\text { [100] }\end{array}$ & 2014 & $\mathrm{~F} / 37$ & $\begin{array}{l}\text { SLE, lupus } \\
\text { nephritis }\end{array}$ & IP & $75 \mu \mathrm{g} / \mathrm{kg} \times 1$ dose & $\mathrm{CS}, \mathrm{CPM}$ & CR & none & 0 \\
\hline $\begin{array}{l}\text { Khoulani } \\
\text { et al. [101] }\end{array}$ & 2014 & $\mathrm{~F} / 51$ & $\begin{array}{l}\text { NHL, lupus } \\
\text { nephritis, cryo- } \\
\text { globulinemia, } \\
\text { bacterial } \\
\text { pneumonia }\end{array}$ & IV & $90 \mu \mathrm{g} / \mathrm{kg} \times 3$ doses & $\begin{array}{c}\text { CS, RTX, } \\
\text { plasmapheresis }\end{array}$ & NR & none & 1 \\
\hline
\end{tabular}


Table 2. Cont.

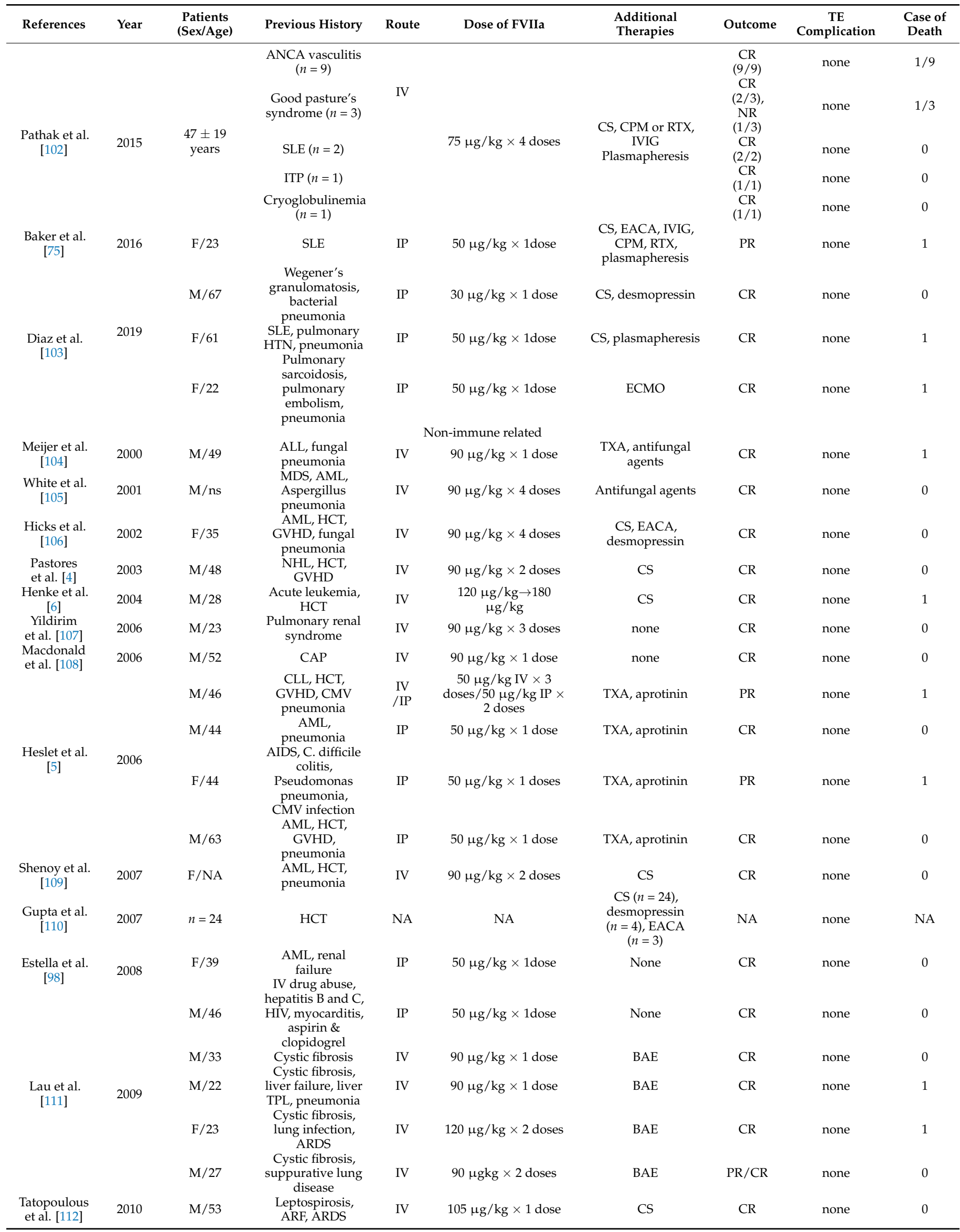


Table 2. Cont

\begin{tabular}{|c|c|c|c|c|c|c|c|c|c|}
\hline References & Year & $\begin{array}{l}\text { Patients } \\
\text { (Sex/Age) }\end{array}$ & Previous History & Route & Dose of FVIIa & $\begin{array}{l}\text { Additional } \\
\text { Therapies }\end{array}$ & Outcome & $\begin{array}{c}\text { TE } \\
\text { Complication }\end{array}$ & $\begin{array}{l}\text { Case of } \\
\text { Death }\end{array}$ \\
\hline $\begin{array}{c}\text { Dabar et al. } \\
\text { [97] }\end{array}$ & 2011 & NA & Leukemia & NA & $90 \mu \mathrm{g} / \mathrm{kg} \times 1$ dose & none & $\mathrm{CR}$ & none & 0 \\
\hline $\begin{array}{c}\text { Elinoff et al. } \\
\text { [96] }\end{array}$ & 2014 & $\begin{array}{c}n=23(\mathrm{M}: \mathrm{F} \\
=13: 10), \text { Age } \\
36(9-66) \\
\text { years }\end{array}$ & $\begin{array}{c}\text { Diagnosis: } \\
\text { ALL }(n=1), \text { AML } \\
(n=3), \text { CLL }(n= \\
\text { 2), HD }(n=1), \\
\text { AA }(n=6), \text { MDS } \\
(n=1), \text { other }(n= \\
\text { 5). Preceding } \\
\text { conditions: HCT } \\
(n=23), \text { CMV }(n \\
=14), \text { aGVHD }(n \\
=1), \text { CGVHD }(n= \\
\text { 8), DLI }(n=6), \\
\text { stem cell boost }(n \\
=5), \text { ARDS }\end{array}$ & IV & $\begin{array}{c}41 \mu \mathrm{g} / \mathrm{kg} \times 3 \mathrm{doses} \\
\text { total dose } 16 \mathrm{mg} \\
(4.8-37.6 \mathrm{mg})\end{array}$ & $\begin{array}{c}\text { CS }(n=23), \\
\text { Desmopressin } \\
(n=8), \text { EACA } \\
(n=2), \text { Estrogen } \\
(n=1)\end{array}$ & NA & $\begin{array}{c}\text { 44/43 episodes: } \\
\text { blood clot } \\
\text { obstruction an } \\
\text { e-tube }(n=1), \\
\text { basilic vein } \\
\text { thrombosis } \\
(n=1) \text {. DIC } \\
(n=2)\end{array}$ & $15 / 23$ \\
\hline \multirow[t]{3}{*}{$\begin{array}{l}\text { Pathak et al. } \\
\text { [102] }\end{array}$} & \multirow[t]{3}{*}{2015} & years & $\mathrm{HCT}(n=7)$ & IV & $75 \mu \mathrm{g} / \mathrm{kg} \times 4$ doses & $\begin{array}{c}\text { CS, CPM or RTX, } \\
\text { IVIG } \\
\text { Plasmapheresis }\end{array}$ & $\begin{array}{c}\text { CR } \\
(7 / 7)\end{array}$ & none & $6 / 7$ \\
\hline & & $\mathrm{F} / 49$ & $\begin{array}{c}\text { MDS, HCT } \\
\text { End-stage liver }\end{array}$ & IP & $30 \mu \mathrm{g} / \mathrm{kg} \times 2$ dose & CS, EACA & CR & none & 0 \\
\hline & & $\mathrm{M} / 64$ & $\begin{array}{l}\text { disease, } \\
\text { clopidogrel } \\
\text { treatment }\end{array}$ & IP & $30 \mu \mathrm{g} / \mathrm{kg} \times 2$ dose & CS & $\mathrm{CR}$ & none & 0 \\
\hline \multirow{3}{*}{$\begin{array}{l}\text { Baker et al. } \\
\text { [75] }\end{array}$} & \multirow{3}{*}{2016} & $\mathrm{~F} / 68$ & $\begin{array}{l}\text { Metastatic anal } \\
\text { cell carcinoma, } \\
\text { ARDS }\end{array}$ & IP & $30 \mu \mathrm{g} / \mathrm{kg} \times 2$ dose & CS & $\mathrm{CR}$ & none & 0 \\
\hline & & $\mathrm{F} / 23$ & HCT & IP & $30 \mu \mathrm{g} / \mathrm{kg} \times 1$ dose & CS & $\mathrm{CR}$ & none & 0 \\
\hline & & $\mathrm{F} / 84$ & $\begin{array}{l}\text { Burn, inhaled } \\
\text { injury }\end{array}$ & IP & $60 \mu \mathrm{g} / \mathrm{kg} \times 1$ dose & CS, EACA & $\mathrm{CR}$ & none & 0 \\
\hline $\begin{array}{l}\text { Diaz et al. } \\
\text { [103] }\end{array}$ & 2019 & $\mathrm{~F} / 46$ & Septic shock & IP & $50 \mu \mathrm{g} / \mathrm{kg} \times 1$ dose & none & CR & none & 0 \\
\hline \multirow[t]{2}{*}{$\begin{array}{l}\text { Shimizu } \\
\text { et al. [113] }\end{array}$} & \multirow[t]{2}{*}{2020} & $\mathrm{M} / 68$ & $\begin{array}{l}\text { Acute ischemic } \\
\text { stroke, t-PA } \\
\text { treatment }\end{array}$ & IV & $75 \mu \mathrm{g} / \mathrm{kg} \times 1$ dose & CS & CR & none & 0 \\
\hline & & $\mathrm{M} / 54$ & $\begin{array}{l}\text { Acute ischemic } \\
\text { stroke, t-PA } \\
\text { treatment }\end{array}$ & IP & $75 \mu \mathrm{g} / \mathrm{kg} \times 1$ dose & CS & $\mathrm{CR}$ & none & 0 \\
\hline
\end{tabular}

Abbreviations: AA, aplastic anemia; EACA, aminocaproic acid; aGVHD, acute graft-versus-host disease; AIDS, acquired immune deficiency syndrome; ALL, acute lymphocytic leukemia; AML, acute myeloid leukemia; ANCA, anti-neutrophil cytoplasmic antibody; APS, antiphospholipid syndrome, ARDS, acute respiratory distress syndrome; BAE, bronchial artery embolization; CAP, community-acquired pneumonia; CLL, chronic lymphocytic leukemia; cGVHD, chronic graft-versus-host disease; CMV, cytomegalovirus; CR, complete response; CPM, cyclophosphamide; CS, corticosteroids; DLI, donor lymphocyte infusion; ECMO, extracorporeal membrane oxygenation; MDS, myeloid dysplastic syndrome; HCT, hematopoietic stem cell transplantation; HD, Hodgkin disease; HIV, human immune deficiency virus; HTN, hypertension; IP, intrapulmonary; ITP, idiopathic thrombocytopenic purpura; IV, intravenously; MMF, mycophenolate mofetil; NA, not available; NHL, non-Hodgkin lymphoma; NR, no response; SLE, systemic lupus erythematosus; PR, partial response; RTX, rituximab; TE, thromboembolic; TPL, transplantation.

\section{Recombinant FVIIa Treatment for DAH in Children}

The off-label use of FVIIa in pediatric patients has also been expanding despite the absence of adequate studies addressing safety and efficacy. According to a multi-center cohort study, $83 \%$ of FVIIa use was off-label, and the off-label use of FVIIa increased 10-fold between 2000 and 2007 [114]. The Haemostasis Registry reported the results of the off-label use of FVIIa in 388 children [115]. The median age was 12 months, and the medians of the first dose and total dose were $114 \mu \mathrm{g} / \mathrm{kg}$ and $1.2 \mathrm{mg}$, respectively. They observed a reduction in the number of transfusions after the use of FVIIa $(p<0.01)$ and a subjective response rate of $82 \%$; thromboembolic complications were reported in $5.4 \%$ to $10.9 \%$ of the patients, which were similar to the published incidence in adults $[79,116,117]$. These results suggest that FVIIa is an effective hemostatic agent in severely ill pediatric patients experiencing life-threatening hemorrhage, and FVIIa can reduce blood product requirements $[2,115,118]$. However, its benefit for neonates and infants less than 1 year of age remains unclear. Young et al reported that neonates had a lower response rate of $47 \%$ and a higher risk of thrombosis (17.6\%) than older aged groups (more than 1 month) [118]. The SeveNBleeP registry, a web-based registry of FVIIa use in non-hemophiliac pediatric patients including 42 infants less than 1 year reported that there was no significant reduction in requirements for blood products after FVIIa treatment and no significant increase in 
thromboembolic complication (2.4\%) [2]. The FVIIa has a shorter half-life and more rapid clearance in children compared with adults; therefore, higher and more frequent doses of FVIIa are often required to control significant bleeding in children, especially in neonates and infants $[2,115,118]$. Considering the relatively poor results of FVIIa and the low levels of natural anticoagulants (proteins $\mathrm{C}$ and $\mathrm{S}$ and antithrombin-III), the risk of thromboembolic complication can increase in neonates and infants, and the risk-to-benefit ratio can be higher, requiring careful decision.

Many causes such as perinatal asphyxia, very low birth weight (VLBW), mechanical ventilation, respiratory distress syndrome (RDS), exogenous surfactant therapy, sepsis, hypothermia, patent ductus arteriosus, and coagulopathies can trigger pulmonary hemorrhage in pediatric patients including neonates $[3,119]$. The FVIIa treatment for pulmonary hemorrhage in pediatric patients is listed in Table 3. Data on 45 children are available, the majority were classified as non-immune related DAH, and only 3 cases were immune related DAH. Among 33 pediatric cases with past history information, 16 cases were associated with hematologic malignancies, 5 cases were associated with HCT, 4 cases were preterm, and 5 cases were related to cardiovascular disease. The overall mortality was $30 \%$ (10 of 33 cases with detailed information), and the pediatric patients with hematologic malignancies showed a high mortality (9 in 16 patients, 56\%). Complete response after treatment of FVIIa was observed in $64.4 \%$, and a partial response (bleeding improved but not ceased) was in $24.4 \%$, with $11.1 \%$ having no response to treatment. Two thromboembolic complications were reported $(4.4 \%)$ [118,120]. Among 45 cases, 29 patients received iv rFVIIa and 16 patients received ip rFVIIa treatment. The mean dose of rFVIIa was 400 $\mu \mathrm{g} / \mathrm{kg}$ per episode (range, $60-3150 \mu \mathrm{g} / \mathrm{kg}$ ) for iv treatment and $46 \mu \mathrm{g} / \mathrm{kg}$ per episode for ip treatment, respectively. However, the outcome for ip rFVIIa was not inferred to iv rFVIIa: among 29 patients who received iv rFVIIa, 15 achieved complete response, 9 showed partial response, and 5 had no response ( $82 \%$ of response rate); among patients who received ip rFVIIa, 14 had complete response and 2 had partial response ( $100 \%$ of response rate). The patients who received iv FVIIa required multiple doses to achieve satisfactory hemostasis. Although these data cannot represent the effect of FVIIa for DAH in pediatrics, iv FVIIa appears to be less effective for DAH than other life-threatening bleedings $[95,118]$. Due to pharmacokinetic characteristics of children, higher and multiple doses of FVIIa may be needed. On the other hand, the patients treated with ip FVIIla showed a significant improvement in their oxygenation capacities $(\mathrm{PaO} 2 / \mathrm{FiO} 2$ ratio) on subsequent days after FVIIa treatment $[89,99]$, and one child experienced thrombotic obstruction in his endotracheal tube (ETT); there was no evidence of intra-alveolar thrombotic deposition (hyaline membrane formation) [120]. We experienced successful immediate hemostasis after treatment of ip FVIIa in pediatric patients with refractory severe DAH which did not respond to other treatments including TXA, high-dose corticosteroids, rituximab, and multiple transfusions [89]. These data showed that pulmonary hemostasis can be induced more easily from the alveolar side than from the endothelial side with reduced systemic risk of complication, suggesting intrapulmonary administration of FVIIa as an effective strategy for DAH in children as well as in adults.

Table 3. Published data on recombinant factor VIIa treatment for diffuse alveolar hemorrhage in children.

\begin{tabular}{|c|c|c|c|c|c|c|c|c|c|}
\hline Reference & Year & $\begin{array}{l}\text { Patients } \\
\text { (Sex/Age) }\end{array}$ & Previous History & Route & Dose of FVIIa & $\begin{array}{l}\text { Additional } \\
\text { Therapies }\end{array}$ & Outcome & $\begin{array}{c}\text { TE } \\
\text { Complication }\end{array}$ & $\begin{array}{c}\text { Case of } \\
\text { Death }\end{array}$ \\
\hline \multicolumn{10}{|c|}{ Immune-related } \\
\hline $\begin{array}{l}\text { Bafaquih } \\
\text { et al. [121] }\end{array}$ & 2015 & $\begin{array}{c}\text { 3/8 patients, } \\
(\mathrm{M}: \mathrm{F}=4: 4) \\
2(0.5-9) \text { years }\end{array}$ & $\begin{array}{l}\text { Connective tissue } \\
\text { disorder }(n=3) \text {, } \\
\text { respiratory infection } \\
(n=3), \operatorname{MOF}(n=1)\end{array}$ & IP & $\begin{array}{c}\text { 35-50 } \mu \mathrm{g} / \mathrm{kg} \times \\
\text { 3-6 dose }\end{array}$ & TXA & $3 \mathrm{CR}$ & none & 0 \\
\hline \multicolumn{10}{|c|}{ Congestive heart failure associated } \\
\hline $\begin{array}{l}\text { Veldman } \\
\text { et al. [122] }\end{array}$ & 2002 & $\mathrm{M} /$ preterm & $\begin{array}{l}\text { VLBW, RDS, PDA, } \\
\text { IVH, PDA ligation }\end{array}$ & IV & $200 \mu \mathrm{g} / \mathrm{kg} \times 2$ doses & none & CR & none & 0 \\
\hline \multirow{2}{*}{$\begin{array}{l}\text { Olomu et al. } \\
\text { [123] }\end{array}$} & \multirow{2}{*}{2002} & $\mathrm{M} /$ preterm & $\begin{array}{l}\text { VLBW, RDS, PDA, } \\
\text { sepsis, DIC, PIE }\end{array}$ & IV & $50 \mu \mathrm{g} / \mathrm{kg} \times 6$ doses & none & $\mathrm{CR}$ & none & 0 \\
\hline & & $\mathrm{F} /$ preterm & $\begin{array}{l}\text { VLBW, RDS, PDA, } \\
\text { Sepsis, DIC }\end{array}$ & IV & $50 \mu \mathrm{g} / \mathrm{kg} \times 16$ doses & none & CR & none & 0 \\
\hline
\end{tabular}


Table 3. Cont.

\begin{tabular}{|c|c|c|c|c|c|c|c|c|c|}
\hline Reference & Year & $\begin{array}{l}\text { Patients } \\
\text { (Sex/Age) }\end{array}$ & Previous History & Route & Dose of FVIIa & $\begin{array}{l}\text { Additional } \\
\text { Therapies }\end{array}$ & Outcome & $\begin{array}{c}\text { TE } \\
\text { Complication }\end{array}$ & $\begin{array}{l}\text { Case of } \\
\text { Death }\end{array}$ \\
\hline $\begin{array}{l}\text { Leibovitch } \\
\text { et al. [124] }\end{array}$ & 2003 & $\mathrm{~F} / 2$ months & $\begin{array}{l}\text { Down syndrome, } \\
\text { CHD, cardiac surgery }\end{array}$ & IV & $100 \mu \mathrm{g} / \mathrm{kg} \times 4$ doses & TXA & $\mathrm{CR}$ & none & 0 \\
\hline $\begin{array}{l}\text { Bafaquih } \\
\text { et al. [121] }\end{array}$ & 2015 & $1 / 8$ patients & $\begin{array}{l}\text { Cardiovascular } \\
\text { disease, ARDS, } \\
\text { infection }\end{array}$ & IP & $\begin{array}{l}\text { 35-50 } \mu \mathrm{g} / \mathrm{kg} \times \\
\text { 3-6 dose }\end{array}$ & TXA & $1 C R$ & none & 0 \\
\hline \multicolumn{10}{|c|}{ Miscellaneous } \\
\hline $\begin{array}{l}\text { Blatt et al. } \\
\text { [125] }\end{array}$ & 2001 & $\mathrm{~F} / 8$ years & AML, HCT, HC & IV & $\begin{array}{c}270 \mu \mathrm{g} / \mathrm{kg} \times 1 \text { dose } \\
\rightarrow 90 \mu \mathrm{g} / \mathrm{kg} \times \\
28 \text { doses }\end{array}$ & CS & PR & none & 1 \\
\hline $\begin{array}{l}\text { Cetin et al. } \\
{[3]}\end{array}$ & 2006 & $\mathrm{M} /$ preterm & $\begin{array}{l}\text { LBW, RDS, sepsis, } \\
\text { DIC }\end{array}$ & IV & $120 \mu \mathrm{g} / \mathrm{kg} \times 3$ doses & none & PR & none & 0 \\
\hline \multirow{2}{*}{$\begin{array}{l}\text { Brady et al. } \\
\text { [94] }\end{array}$} & 2006 & $\mathrm{~F} / 2$ days & $\begin{array}{l}\text { MMA, DIC, HD for } \\
\text { hyperammonemia }\end{array}$ & IV & $90 \mu \mathrm{g} / \mathrm{kg} \times 2$ doses & & $\mathrm{CR}$ & none & 1 \\
\hline & 2006 & $\begin{array}{l}\text { M/ } 2 \text { days } \\
\text { NA/ } 0 \text { days }\end{array}$ & $\begin{array}{l}\text { Pseudomonal sepsis } \\
\text { MAS, ventilator care }\end{array}$ & IV & $\begin{array}{c}90 \mu \mathrm{g} / \mathrm{kg} \times 1 \text { dose } \\
170 \mu \mathrm{g} / \mathrm{kg} \times 1 \text { dose }\end{array}$ & EACA & $\begin{array}{l}\mathrm{CR} \\
\mathrm{CR}\end{array}$ & $\begin{array}{l}\text { none } \\
\text { none }\end{array}$ & $\begin{array}{l}0 \\
0\end{array}$ \\
\hline \multirow{2}{*}{$\begin{array}{l}\text { Grizelj et al. } \\
\text { [126] }\end{array}$} & & NA/13 days & $\begin{array}{l}\text { HLH, postsurgical } \\
\text { resuscitation }\end{array}$ & IV & $130 \mu \mathrm{g} / \mathrm{kg} \times 1$ dose & EACA & CR & none & 0 \\
\hline & & $\mathrm{NA} / 2$ days & $\begin{array}{l}\text { HLH, postsurgical } \\
\text { resuscitation }\end{array}$ & & $222 \mu \mathrm{g} / \mathrm{kg} \times 1$ dose & EACA & CR & none & 0 \\
\hline $\begin{array}{l}\text { Young et al. } \\
\text { [119] }\end{array}$ & 2009 & 12 patients & NA & IV & $\begin{array}{c}90 \mu \mathrm{g} / \mathrm{kg} \times 1 \text { dose } \\
(\text { range, } 20.3-353 \\
\mu \mathrm{g} / \mathrm{kg})\end{array}$ & & $\begin{array}{l}4 \mathrm{CR}, 5 \mathrm{PR}, \\
\text { 3NR }\end{array}$ & $\begin{array}{l}1 \mathrm{LV} \\
\text { thrombus }\end{array}$ & NA \\
\hline \multirow{5}{*}{$\begin{array}{l}\text { Bhat et al. } \\
\text { [95] }\end{array}$} & 2011 & $\mathrm{M} / 14$ years & DSS, sepsis & IV & $70 \mu \mathrm{g} / \mathrm{kg} \times 1$ dose & Anti-D & CR & none & 0 \\
\hline & & $\mathrm{M} / 13$ years & $\begin{array}{l}\text { AML, TLS, ARF, acute } \\
\text { pancreatitis }\end{array}$ & IV & $90 \mu \mathrm{g} / \mathrm{kg} \times 1$ dose & none & PR & none & 1 \\
\hline & & $\mathrm{F} / 9$ years & $\begin{array}{l}\text { Thalassemia, major, } \\
\text { HCT, ARDS }\end{array}$ & IV & $90 \mu \mathrm{g} / \mathrm{kg} \times 1$ dose & octreotide & CR & none & 0 \\
\hline & & F/13 years & $\begin{array}{l}\text { ALL, febrile } \\
\text { neutropenia, sepsis }\end{array}$ & IV & $70 \mu \mathrm{g} / \mathrm{kg} \times 1$ dose & none & NR & none & 1 \\
\hline & & M/10 years & AML & IV & $75 \mu \mathrm{g} / \mathrm{kg} \times 1$ dose & none & NR & none & 1 \\
\hline $\begin{array}{l}\text { Colin et al. } \\
\text { [126] }\end{array}$ & 2010 & $\mathrm{M} / 17$ years & $\begin{array}{l}\text { AML, pancytopenia, } \\
\text { sepsis }\end{array}$ & IP & $50 \mu \mathrm{g} / \mathrm{kg} \times 1$ dose & CS & CR & none & 0 \\
\hline $\begin{array}{l}\text { Larcombe } \\
\text { et al. [99] }\end{array}$ & 2014 & $\mathrm{M} / 2$ years & $\begin{array}{l}\text { AML, HCT, hepatic } \\
\text { SOS, GVHD }\end{array}$ & IP & $50 \mu \mathrm{g} / \mathrm{kg} \times 1$ dose & None & CR & $\begin{array}{c}\text { ETT } \\
\text { thrombus }\end{array}$ & 0 \\
\hline \multirow[t]{5}{*}{$\begin{array}{l}\text { Park et al. } \\
\text { [81] }\end{array}$} & 2015 & $\mathrm{~F} / 11$ years & MDS, HCT, HC, TMA & IP & $60 \mu \mathrm{g} / \mathrm{kg} \times 1$ dose & $\begin{array}{l}\text { CS, TXA, } \\
\text { RTX }\end{array}$ & $\mathrm{CR}$ & none & 1 \\
\hline & & M/15 years & $\begin{array}{l}\text { AML, DIC, cytarabine } \\
\text { syndrome } \\
\text { T-LL, chickenpox }\end{array}$ & IP & $45 \mu \mathrm{g} / \mathrm{kg} \times 1$ dose & CS & CR & none & 0 \\
\hline & & $\mathrm{M} / 6$ years & $\begin{array}{l}\text { infection, hepatic } \\
\text { sinusoidal obstruction } \\
\text { syndrome }\end{array}$ & IP & $43 \mu \mathrm{g} / \mathrm{kg} \times 1$ dose & CS & CR & none & 0 \\
\hline & & $\mathrm{M} / 14$ years & $\begin{array}{l}\text { AML, DIC } \\
\text { HLH, HCT, CMV }\end{array}$ & IP & $52 \mu \mathrm{g} / \mathrm{kg} \times 1$ dose & CS & CR & none & 0 \\
\hline & & F/10 months & $\begin{array}{l}\text { infection, hepatic } \\
\text { sinusoidal obstruction } \\
\text { syndrome }\end{array}$ & IP & $63 \mu \mathrm{g} / \mathrm{kg} \times 1$ dose & $\begin{array}{l}\text { CS, TXA, } \\
\text { RTX }\end{array}$ & $\mathrm{CR}$ & none & 1 \\
\hline $\begin{array}{l}\text { Bafaquih } \\
\text { et al. [121] }\end{array}$ & 2015 & $\begin{array}{l}\text { 4/8 patients, } \\
(\mathrm{M}: \mathrm{F}=4: 4), 2 \\
(0.5-9) \text { years }\end{array}$ & $\begin{array}{l}\text { Connective tissue } \\
\text { disorder }(n=3), \\
\text { respiratory infection } \\
(n=7), \text { MOF }(n=1), \\
\text { cardiovascular } \\
\text { disease }(n=1), \text { ALL } \\
(n=1), \operatorname{HLH}(n=1)\end{array}$ & IP & $35-50 \mu \mathrm{g} / \mathrm{kg} \times 1$ dose & TXA & $2 \mathrm{CR}, 2 \mathrm{PR}$ & none & $2 / 8$ \\
\hline \multicolumn{10}{|c|}{ Idiopathic } \\
\hline $\begin{array}{l}\text { Bhat et al. } \\
\text { [95] }\end{array}$ & 2011 & $\mathrm{~F} / 6$ years & $\begin{array}{l}\text { IPH, pneumothorax, } \\
\text { and septic shock }\end{array}$ & IV & $60 \mu \mathrm{g} / \mathrm{kg} \times 1$ dose & none & PR & none & 1 \\
\hline $\begin{array}{l}\text { Park et al. } \\
\text { [81] }\end{array}$ & 2015 & $\mathrm{~F} / 11$ years & $\mathrm{IPH}$ & IP & $57 \mu \mathrm{g} / \mathrm{kg} \times 1$ dose & CS & CR & none & 0 \\
\hline
\end{tabular}

Abbreviations: ALL, acute lymphocytic leukemia; EACA, aminocaproic acid; AML, acute myeloid leukemia; ARDS, acute respiratory distress syndrome; ARF, acute renal failure; $\mathrm{CHD}$, complex heart disease; $\mathrm{CMV}$, cytomegalovirus; CR, complete response; $\mathrm{CPM}$, cyclophosphamide; CS, corticosteroids; DIC, disseminated intravascular coagulation; DSS, Dengue shock syndrome; ETT, endotracheal tube; GVHD, graft-versus-host disease; HC, hemorrhagic cystitis; HCT, hematopoietic stem cell transplantation; HD, hemodialysis; HLH, hemophagocytic lymphohistiocytosis; HLHS, hypoplastic left heart syndrome; IP, intrapulmonary; IPH, idiopathic pulmonary hemosiderosis; IV, intravenously; IVH, intraventricular hemorrhage; LBW, low birth weight; LV, left ventricle; MAS, meconium aspiration syndrome; MDS, myelodysplastic syndrome; MMA, methylmalonic aciduria; NA, not available; NR, no response; PDA, patent ductus arteriosus; PIE, pulmonary interstitial emphysema; PR, partial response; RDS, respiratory distress syndrome; SOS, sinusoidal obstruction syndrome; TE, thromboembolic; T-LL, T-cell lymphoblastic lymphoma; TLS, tumor lysis syndrome; TMA, thrombotic microangiopathy; VLBW, very low birth weight.

\section{Conclusions}

DAH should be suspected in any patient with alveolar infiltrates on chest radiographs, hypoxemia, anemia, and hemoptysis. DAH is a clinical syndrome that can be a manifestation of multiple different etiologies, and identifying the underlying etiology is important 
to determine treatment strategy. In life-threatening DAH, rapid and effective hemostasis along with the appropriate treatment for the underlying disease contributes to patient survival. Considering the substantial risk of thromboembolic complications with the use of a large amount of FVIIa, intrapulmonary administration of relatively small-dosed FVIIa could be an effective and reasonable treatment option for DAH in pediatric patients as well as in adults, requiring a prospective or randomized trial to verify the effect and standardize the FVIIla treatment. However, most importantly, many studies including our case series have suggested that instant hemostasis alone cannot ensure successful treatment outcome without successful treatment of primary disease or inflammation. We have experienced a refractory hemophagocytic lymphohistiocytosis (HLH) pediatric case presented with severe DAH (unpublished data). Although immediate and near complete hemostasis was achieved after intrapulmonary FVIIa instillations, the patients experienced multiple episodes of profound DAH and expired with sepsis and multiorgan failure, strongly implicating the importance of a multidisciplinary treatment approach for a successful outcome.

Funding: This research received Sloan Kettering Open Access Publication (SKOAP) fund.

Institutional Review Board Statement: Not applicable.

Informed Consent Statement: Not applicable.

Data Availability Statement: Data is contained within the article.

Acknowledgments: I would like to thank the library service at MSKCC for assistance in literature search. In addition, I appreciate Nai-Kong V. Cheung for his constant support and Byung-Ju Kim, YunJung Hur, Min-Seop Song, Mee-Rim Jung, Tae-kyu Hwang, and nursing staffs in the Inje University Haeundae Paik Hospital for their help and devotion to the patients.

Conflicts of Interest: The author declare that the research was conducted without any commercial or financial relationships that could be construed as a potential conflict of interest.

$\begin{array}{ll}\text { Abbreviations } \\ \text { AAV } & \text { ANCA-associated vasculitis } \\ \text { ANA } & \text { anti-nuclear antibody } \\ \text { ANCA } & \text { anti-neutrophilic cytoplasmic antibody } \\ \text { APL } & \text { anti-phospholipid antibody } \\ \text { ARDS } & \text { Acute respiratory distress syndrome } \\ \text { BAL } & \text { bronchoalveolar lavage } \\ \text { B2GP } & \text { 3-2glycoprotein1 } \\ \text { CL } & \text { anti-cardiolipin antibody } \\ \text { CR } & \text { complete response } \\ \text { CT } & \text { Chest computed tomography } \\ \text { DAH } & \text { Diffuse alveolar hemorrhage } \\ \text { DAMPs } & \text { danger-associated molecular patterns } \\ \text { EACA } & \text { Epsilon-amino-caproic acid } \\ \text { ESRD } & \text { end-stage renal disease } \\ \text { ETT } & \text { Endotracheal tube } \\ \text { GBM } & \text { Glomerular basement membrane } \\ \text { GVHD } & \text { graft-versus-host disease } \\ \text { HCT } & \text { Hematopoietic stem cell transplantation } \\ \text { HLH } & \text { Hemophagocytic lymphohistiocytosis } \\ \text { ICU } & \text { Intensive care unit } \\ \text { IPH } & \text { Idiopathic pulmonary hemosiderosis } \\ \text { NET } & \text { Neutrophil extra-cellular traps } \\ \text { NR } & \text { No response } \\ \text { PEEP } & \text { Positive end-expiratory pressure } \\ \text { PR } & \text { Partial response } \\ \text { RDS } & \text { Respiratory distress syndrome } \\ & \end{array}$




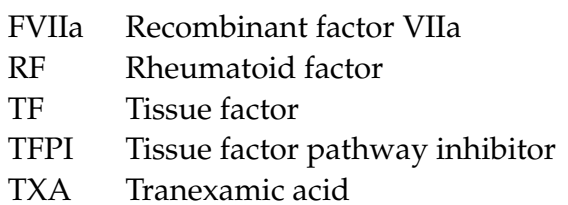

\section{References}

1. Collard, H.R.; Schwarz, M.I. Diffuse alveolar hemorrhage. Clin. Chest Med. 2004, 25, 583-592. [CrossRef] [PubMed]

2. Blatny, J.; Mathew, P.; Monagle, P.; Ovesna, P.; Fiamoli, V. Safety and efficacy of recombinant activated factor VII in nonhemophilia children with severe or life-threatening bleeding: A report from the SeveNBleeP registry. Blood Coagul. Fibrinolysis 2014, 25, 326-332. [CrossRef] [PubMed]

3. Cetin, H.; Yalaz, M.; Akisu, M.; Karapinar, D.Y.; Kavakli, K.; Kultursay, N. The use of recombinant activated factor VII in the treatment of massive pulmonary hemorrhage in a preterm infant. Blood Coagul. Fibrinolysis 2006, 17, 213-216. [CrossRef]

4. Pastores, S.M.; Papadopoulos, E.; Voigt, L.; Halpern, N.A. Diffuse alveolar hemorrhage after allogeneic hematopoietic stem-cell transplantation: Treatment with recombinant factor VIIa. Chest 2003, 124, 2400-2403. [CrossRef]

5. Heslet, L.; Nielsen, J.D.; Levi, M.; Sengelov, H.; Johansson, P.I. Successful pulmonary administration of activated recombinant factor VII in diffuse alveolar hemorrhage. Crit. Care 2006, 10, R177. [CrossRef]

6. Henke, D.; Falk, R.J.; Gabriel, D.A. Successful treatment of diffuse alveolar hemorrhage with activated factor VII. Ann. Intern. Med. 2004, 140, 493-494. [CrossRef]

7. Heslet, L.; Nielsen, J.D.; Nepper-Christensen, S. Local pulmonary administration of factor VIIa (rFVIIa) in diffuse alveolar hemorrhage (DAH) - A review of a new treatment paradigm. Biologics 2012, 6, 37-46.

8. Ioachimescu, O.C.; Stoller, J.K. Diffuse alveolar hemorrhage: Diagnosing it and finding the cause. Clevel. Clin. J. Med. 2008, 75, 258. [CrossRef]

9. Lara, A.R.; Schwarz, M.I. Diffuse alveolar hemorrhage. Chest 2010, 137, 1164-1171. [CrossRef]

10. Newsome, B.R.; Morales, J.E. Diffuse alveolar hemorrhage. South. Med. J. 2011, 104, 269-274. [CrossRef]

11. Colby, T.V.; Fukuoka, J.; Ewaskow, S.P.; Helmers, R.; Leslie, K.O. Pathologic approach to pulmonary hemorrhage. Ann. Diagn. Pathol. 2001, 5, 309-319. [CrossRef] [PubMed]

12. Cordier, J.F.; Cottin, V. Alveolar hemorrhage in vasculitis: Primary and secondary. Semin. Respir. Crit. Care Med. 2011, 32, 310-321. [CrossRef] [PubMed]

13. Maldonado, F.; Parambil, J.G.; Yi, E.S.; Decker, P.A.; Ryu, J.H. Haemosiderin-laden macrophages in the bronchoalveolar lavage fluid of patients with diffuse alveolar damage. Eur. Respir. J. 2009, 33, 1361-1366. [CrossRef]

14. Castro, C.Y. ARDS and diffuse alveolar damage: A pathologist's perspective. Semin. Thorac. Cardiovasc. Surg. 2006, 18, 13-19. [CrossRef]

15. Parambil, J.G.; Myers, J.L.; Aubry, M.C.; Ryu, J.H. Causes and prognosis of diffuse alveolar damage diagnosed on surgical lung biopsy. Chest 2007, 132, 50-57. [CrossRef]

16. Park, M.S. Diffuse alveolar hemorrhage. Tuberc. Respir. Dis. 2013, 74, 151-162. [CrossRef]

17. Aggarwal, N.R.; King, L.S.; D'Alessio, F.R. Diverse macrophage populations mediate acute lung inflammation and resolution. Am. J. Physiol. Lung Cell. Mol. Physiol. 2014, 306, L709-L725. [CrossRef]

18. Franks, T.J.; Koss, M.N. Pulmonary capillaritis. Curr. Opin. Pulm. Med. 2000, 6, 430-435. [CrossRef]

19. Zhuang, H.; Han, S.; Lee, P.Y.; Khaybullin, R.; Shumyak, S.; Lu, L.; Chatha, A.; Afaneh, A.; Zhang, Y.; Xie, C.; et al. Pathogenesis of Diffuse Alveolar Hemorrhage in Murine Lupus. Arthritis Rheumatol. 2017, 69, 1280-1293. [CrossRef]

20. Short, K.R.; Kroeze, E.; Fouchier, R.A.M.; Kuiken, T. Pathogenesis of influenza-induced acute respiratory distress syndrome. Lancet Infect. Dis. 2014, 14, 57-69. [CrossRef]

21. Brinkmann, V.; Reichard, U.; Goosmann, C.; Fauler, B.; Uhlemann, Y.; Weiss, D.S.; Weinrauch, Y.; Zychlinsky, A. Neutrophil extracellular traps kill bacteria. Science 2004, 303, 1532-1535. [CrossRef]

22. Mistry, P.; Carmona-Rivera, C.; Ombrello, A.K.; Hoffmann, P.; Seto, N.L.; Jones, A.; Stone, D.L.; Naz, F.; Carlucci, P.; Dell'Orso, S.; et al. Dysregulated neutrophil responses and neutrophil extracellular trap formation and degradation in PAPA syndrome. Ann. Rheum. Dis. 2018, 77, 1825-1833. [CrossRef] [PubMed]

23. Kaplan, M.J.; Radic, M. Neutrophil extracellular traps: Double-edged swords of innate immunity. J. Immunol. 2012, 189, 2689-2695. [CrossRef] [PubMed]

24. Lee, K.H.; Kronbichler, A.; Park, D.D.; Park, Y.; Moon, H.; Kim, H.; Choi, J.H.; Choi, Y.; Shim, S.; Lyu, I.S.; et al. Neutrophil extracellular traps (NETs) in autoimmune diseases: A comprehensive review. Autoimmun. Rev. 2017, 16, 1160-1173. [CrossRef] [PubMed]

25. Jarrot, P.A.; Tellier, E.; Plantureux, L.; Crescence, L.; Robert, S.; Chareyre, C.; Daniel, L.; Secq, V.; Garcia, S.; Dignat-George, F.; et al. Neutrophil extracellular traps are associated with the pathogenesis of diffuse alveolar hemorrhage in murine lupus. $J$. Autoimmun. 2019, 100, 120-130. [CrossRef]

26. Liu, S.; Su, X.; Pan, P.; Zhang, L.; Hu, Y.; Tan, H.; Wu, D.; Liu, B.; Li, H.; Li, Y.; et al. Neutrophil extracellular traps are indirectly triggered by lipopolysaccharide and contribute to acute lung injury. Sci. Rep. 2016, 6, 37252. [CrossRef] 
27. Afessa, B.; Tefferi, A.; Litzow, M.R.; Krowka, M.J.; Wylam, M.E.; Peters, S.G. Diffuse alveolar hemorrhage in hematopoietic stem cell transplant recipients. Am. J. Respir. Crit. Care Med. 2002, 166, 641-645. [CrossRef]

28. Sisson, J.H.; Thompson, A.B.; Anderson, J.R.; Robbins, R.A.; Spurzem, J.R.; Spence, P.R.; Reed, E.C.; Armitage, J.O.; Vose, J.M.; Arneson, M.A. Airway inflammation predicts diffuse alveolar hemorrhage during bone marrow transplantation in patients with Hodgkin disease. Am. Rev. Respir. Dis. 1992, 146, 439-443. [CrossRef]

29. Piguet, P.F.; Grau, G.E.; Collart, M.A.; Vassalli, P.; Kapanci, Y. Pneumopathies of the graft-versus-host reaction. Alveolitis associated with an increased level of tumor necrosis factor mRNA and chronic interstitial pneumonitis. Lab. Investig. 1989, 61, 37-45.

30. Capizzi, S.A.; Kumar, S.; Huneke, N.E.; Gertz, M.A.; Inwards, D.J.; Litzow, M.R.; Lacy, M.Q.; Gastineau, D.A.; Prakash, U.B.; Tefferi, A. Peri-engraftment respiratory distress syndrome during autologous hematopoietic stem cell transplantation. Bone Marrow Transplant. 2001, 27, 1299-1303. [CrossRef]

31. Srivastava, A.; Gottlieb, D.; Bradstock, K.F. Diffuse alveolar haemorrhage associated with microangiopathy after allogeneic bone marrow transplantation. Bone Marrow Transplant. 1995, 15, 863-867. [PubMed]

32. Agustí, C.; Ramirez, J.; Picado, C.; Xaubet, A.; Carreras, E.; Ballester, E.; Torres, A.; Battochia, C.; Rodriguez-Roisin, R. Diffuse alveolar hemorrhage in allogeneic bone marrow transplantation. A postmortem study. Am. J. Respir. Crit. Care Med. 1995, 151, 1006-1010. [PubMed]

33. Roychowdhury, M.; Pambuccian, S.E.; Aslan, D.L.; Jessurun, J.; Rose, A.G.; Manivel, J.C.; Gulbahce, H.E. Pulmonary complications after bone marrow transplantation: An autopsy study from a large transplantation center. Arch. Pathol. Lab. Med. 2005, 129, 366-371. [PubMed]

34. Koh, H.; Nakamae, H.; Koh, K.R.; Ohsawa, M.; Nakane, T.; Takeoka, Y.; Aimoto, R.; Aimoto, M.; Wada-Inoue, E.; Terada, Y.; et al. Serum cytokine profiles at the onset of severe, diffuse alveolar hemorrhage complicating allogeneic hematopoietic stem cell transplantation, treated successfully with pulse intravenous cyclophosphamide. Acta Haematol. 2010, 124, 171-175. [CrossRef] [PubMed]

35. Krause, M.L.; Cartin-Ceba, R.; Specks, U.; Peikert, T. Update on diffuse alveolar hemorrhage and pulmonary vasculitis. Immunol. Allergy Clin. N. Am. 2012, 32, 587-600. [CrossRef] [PubMed]

36. De Lassence, A.; Fleury-Feith, J.; Escudier, E.; Beaune, J.; Bernaudin, J.F.; Cordonnier, C. Alveolar hemorrhage. Diagnostic criteria and results in 194 immunocompromised hosts. Am. J. Respir. Crit. Care Med. 1995, 151, 157-163. [CrossRef] [PubMed]

37. Perez-Arellano, J.L.; Losa Garcia, J.E.; Garcia Macias, M.C.; Gomez Gomez, F.; Jimenez Lopez, A.; de Castro, S. Hemosiderin-laden macrophages in bronchoalveolar lavage fluid. Acta Cytol. 1992, 36, $26-30$.

38. Golde, D.W.; Drew, W.L.; Klein, H.Z.; Finley, T.N.; Cline, M.J. Occult pulmonary haemorrhage in leukaemia. Br. Med. J. 1975, 2, 166-168. [CrossRef]

39. Travis, W.D.; Colby, T.V.; Lombard, C.; Carpenter, H.A. A clinicopathologic study of 34 cases of diffuse pulmonary hemorrhage with lung biopsy confirmation. Am. J. Surg. Pathol. 1990, 14, 1112-1125. [CrossRef]

40. Susarla, S.C.; Fan, L.L. Diffuse alveolar hemorrhage syndromes in children. Curr. Opin. Pediatr. 2007, 19, 314-320. [CrossRef]

41. Park, J.A. Diffuse alveolar hemorrhage and recombinant factor VIIa treatment in pediatric patients. Korean J. Pediatr. 2016, 59, 105-113. [CrossRef] [PubMed]

42. Kirby, R.R.; Downs, J.B.; Civetta, J.M.; Modell, J.H.; Dannemiller, F.J.; Klein, E.F.; Hodges, M. High level positive end expiratory pressure (PEEP) in acute respiratory insufficiency. Chest 1975, 67, 156-163. [CrossRef] [PubMed]

43. Bellani, G.; Laffey, J.G.; Pham, T.; Fan, E.; Brochard, L.; Esteban, A.; Gattinoni, L.; van Haren, F.; Larsson, A.; McAuley, D.F.; et al. Epidemiology, Patterns of Care, and Mortality for Patients With Acute Respiratory Distress Syndrome in Intensive Care Units in 50 Countries. JAMA 2016, 315, 788-800. [CrossRef] [PubMed]

44. Gattinoni, L.; Collino, F.; Maiolo, G.; Rapetti, F.; Romitti, F.; Tonetti, T.; Vasques, F.; Quintel, M. Positive end-expiratory pressure: How to set it at the individual level. Ann. Transl. Med. 2017, 5, 288. [CrossRef]

45. Heggen, J.; West, C.; Olson, E.; Olson, T.; Teague, G.; Fortenberry, J.; Yeager, A.M. Diffuse alveolar hemorrhage in pediatric hematopoietic cell transplant patients. Pediatrics 2002, 109, 965-971. [CrossRef]

46. Raptis, A.; Mavroudis, D.; Suffredini, A.; Molldrem, J.; Rhee, F.V.; Childs, R.; Phang, S.; Barrett, A. High-dose corticosteroid therapy for diffuse alveolar hemorrhage in allogeneic bone marrow stem cell transplant recipients. Bone Marrow Transplant. 1999, 24, 879-883. [CrossRef]

47. Majhail, N.S.; Parks, K.; Defor, T.E.; Weisdorf, D.J. Diffuse alveolar hemorrhage and infection-associated alveolar hemorrhage following hematopoietic stem cell transplantation: Related and high-risk clinical syndromes. Biol. Blood Marrow Transplant. 2006, 12, 1038-1046. [CrossRef]

48. Rathi, N.K.; Tanner, A.R.; Dinh, A.; Dong, W.; Feng, L.; Ensor, J.; Wallace, S.K.; Haque, S.A.; Rondon, G.; Price, K.J.; et al. Low-, medium- and high-dose steroids with or without aminocaproic acid in adult hematopoietic SCT patients with diffuse alveolar hemorrhage. Bone Marrow Transplant. 2015, 50, 420-426. [CrossRef]

49. Walsh, M.; Merkel, P.A.; Peh, C.A.; Szpirt, W.M.; Puéchal, X.; Fujimoto, S.; Hawley, C.M.; Khalidi, N.; Floßmann, O.; Wald, R.; et al. Plasma Exchange and Glucocorticoids in Severe ANCA-Associated Vasculitis. N. Engl. J. Med. 2020, 382, 622-631. [CrossRef]

50. Klemmer, P.J.; Chalermskulrat, W.; Reif, M.S.; Hogan, S.L.; Henke, D.C.; Falk, R.J. Plasmapheresis therapy for diffuse alveolar hemorrhage in patients with small-vessel vasculitis. Am. J. Kidney Dis. 2003, 42, 1149-1153. [CrossRef] 
51. Gallagher, H.; Kwan, J.T.; Jayne, D.R. Pulmonary renal syndrome: A 4-year, single-center experience. Am. J. Kidney Dis 2002, 39, 42-47. [CrossRef]

52. Nishimura, K.; Waki, D.; Kadoba, K.; Mukoyama, H.; Yokota, T.; Murabe, H. Efficacy of Plasma Exchange in Anti-Neutrophil Cytoplasmic Antibody-Associated Vasculitis. Ther. Apher. Dial. 2019, 23, 248-252. [CrossRef] [PubMed]

53. Walsh, M.; Casian, A.; Flossmann, O.; Westman, K.; Höglund, P.; Pusey, C.; Jayne, D.R. Long-term follow-up of patients with severe ANCA-associated vasculitis comparing plasma exchange to intravenous methylprednisolone treatment is unclear. Kidney Int. 2013, 84, 397-402. [CrossRef] [PubMed]

54. Szczepiorkowski, Z.M.; Winters, J.L.; Bandarenko, N.; Kim, H.C.; Linenberger, M.L.; Marques, M.B.; Sarode, R.; Schwartz, J.; Weinstein, R.; Shaz, B.H.; et al. Guidelines on the use of therapeutic apheresis in clinical practice-evidence-based approach from the Apheresis Applications Committee of the American Society for Apheresis. J. Clin. Apher. 2010, 25, 83-177. [CrossRef] [PubMed]

55. Walsh, M.; Jayne, D. Rituximab in the treatment of anti-neutrophil cytoplasm antibody associated vasculitis and systemic lupus erythematosus: Past, present and future. Kidney Int. 2007, 72, 676-682. [CrossRef]

56. Jones, R.B.; Ferraro, A.J.; Chaudhry, A.N.; Brogan, P.; Salama, A.D.; Smith, K.G.; Savage, C.O.; Jayne, D.R. A multicenter survey of rituximab therapy for refractory antineutrophil cytoplasmic antibody-associated vasculitis. Arthritis Rheum. 2009, 60, 2156-2168. [CrossRef]

57. Keogh, K.A.; Wylam, M.E.; Stone, J.H.; Specks, U. Induction of remission by B lymphocyte depletion in eleven patients with refractory antineutrophil cytoplasmic antibody-associated vasculitis. Arthritis Rheum. 2005, 52, 262-268. [CrossRef]

58. Stone, J.H.; Merkel, P.A.; Spiera, R.; Seo, P.; Langford, C.A.; Hoffman, G.S.; Kallenberg, C.G.; St Clair, E.W.; Turkiewicz, A.; Tchao, N.K.; et al. Rituximab versus cyclophosphamide for ANCA-associated vasculitis. N. Engl. J. Med. 2010, 363, 221-232. [CrossRef]

59. Keogh, K.A.; Ytterberg, S.R.; Fervenza, F.C.; Carlson, K.A.; Schroeder, D.R.; Specks, U. Rituximab for refractory Wegener's granulomatosis: Report of a prospective, open-label pilot trial. Am. J. Respir. Crit. Care Med. 2006, 173, 180-187. [CrossRef]

60. Cartin-Ceba, R.; Fervenza, F.C.; Specks, U. Treatment of antineutrophil cytoplasmic antibody-associated vasculitis with rituximab. Curr. Opin. Rheumatol. 2012, 24, 15-23. [CrossRef]

61. Jones, R.B.; Tervaert, J.W.; Hauser, T.; Luqmani, R.; Morgan, M.D.; Peh, C.A.; Savage, C.O.; Segelmark, M.; Tesar, V.; van Paassen, P.; et al. Rituximab versus cyclophosphamide in ANCA-associated renal vasculitis. N. Engl. J. Med. 2010, 363, 211-220. [CrossRef] [PubMed]

62. Mannucci, P.M. Hemostatic drugs. N. Engl. J. Med. 1998, 339, 245-253. [CrossRef] [PubMed]

63. Solomonov, A.; Fruchter, O.; Zuckerman, T.; Brenner, B.; Yigla, M. Pulmonary hemorrhage: A novel mode of therapy. Respir. Med. 2009, 103, 1196-1200. [CrossRef] [PubMed]

64. O'Neil, E.R.; Schmees, L.R.; Resendiz, K.; Justino, H.; Anders, M.M. Inhaled Tranexamic Acid as a Novel Treatment for Pulmonary Hemorrhage in Critically Ill Pediatric Patients: An Observational Study. Crit. Care Explor. 2020, 2, e0075. [CrossRef] [PubMed]

65. Bafaqih, H.; Chehab, M.; Almohaimeed, S.; Thabet, F.; Alhejaily, A.; AlShahrani, M.; Zolaly, M.A.; Abdelmoneim, A.A.; Abd, E.S. Pilot trial of a novel two-step therapy protocol using nebulized tranexamic acid and recombinant factor VIIa in children with intractable diffuse alveolar hemorrhage. Ann. Saudi Med. 2015, 35, 231-239. [CrossRef]

66. Sanz, M.A.; Montesinos, P. Open issues on bleeding and thrombosis in acute promyelocytic leukemia. Thromb. Res. 2010, 125 (Suppl. 2), S51-S54. [CrossRef]

67. Sander, M.; Spies, C.D.; Martiny, V.; Rosenthal, C.; Wernecke, K.D.; von Heymann, C. Mortality associated with administration of high-dose tranexamic acid and aprotinin in primary open-heart procedures: A retrospective analysis. Crit. Care 2010, 14, R148. [CrossRef]

68. Marshall, A.; Li, A.; Drucker, A.; Dzik, W. Aminocaproic acid use in hospitalized patients with hematological malignancy: A case series. Hematol. Oncol. 2016, 34, 147-153. [CrossRef]

69. Wanko, S.O.; Broadwater, G.; Folz, R.J.; Chao, N.J. Diffuse alveolar hemorrhage: Retrospective review of clinical outcome in allogeneic transplant recipients treated with aminocaproic acid. Biol. Blood Marrow Transplant. 2006, 12, 949-953. [CrossRef]

70. Tsukamoto, T.; Sasaki, H.; Nakamura, H. Treatment of hemoptysis patients by thrombin and fibrinogen-thrombin infusion therapy using a fiberoptic bronchoscope. Chest 1989, 96, 473-476. [CrossRef]

71. de Gracia, J.; de la Rosa, D.; Catalán, E.; Alvarez, A.; Bravo, C.; Morell, F. Use of endoscopic fibrinogen-thrombin in the treatment of severe hemoptysis. Respir. Med. 2003, 97, 790-795. [CrossRef]

72. Lee, J.; Rhee, C.K.; Kim, S.C.; Kim, Y.K.; Kim, H.J.; Lee, S.; Cho, S.G.; Lee, J.W. Use of intrapulmonary administration of thrombin in hematological malignancy patients with alveolar haemorrhage: A case series. Medicine 2020, 99, e20284. [CrossRef]

73. Göbel, K.; Eichler, S.; Wiendl, H.; Chavakis, T.; Kleinschnitz, C.; Meuth, S.G. The Coagulation Factors Fibrinogen, Thrombin, and Factor XII in Inflammatory Disorders-A Systematic Review. Front. Immunol. 2018, 9, 1731. [CrossRef] [PubMed]

74. Lew, W.K.; Weaver, F.A. Clinical use of topical thrombin as a surgical hemostat. Biologics 2008, 2, 593-599.

75. Baker, M.S.; Diab, K.J.; Carlos, W.G.; Mathur, P. Intrapulmonary Recombinant Factor VII as an Effective Treatment for Diffuse Alveolar Hemorrhage: A Case Series. J. Bronchol. Interv. Pulmonol. 2016, 23, 255-258. [CrossRef] [PubMed]

76. Schultz, M.J.; Haitsma, J.J.; Zhang, H.; Slutsky, A.S. Pulmonary coagulopathy as a new target in therapeutic studies of acute lung injury or pneumonia-A review. Crit. Care Med. 2006, 34, 871-877. [CrossRef] [PubMed]

77. Schultz, M.J.; Millo, J.; Levi, M.; Hack, C.E.; Weverling, G.J.; Garrard, C.S.; van der Poll, T. Local activation of coagulation and inhibition of fibrinolysis in the lung during ventilator associated pneumonia. Thorax 2004, 59, 130-135. [CrossRef] 
78. Levi, M.; Schultz, M.J.; Rijneveld, A.W.; van der Poll, T. Bronchoalveolar coagulation and fibrinolysis in endotoxemia and pneumonia. Crit. Care Med. 2003, 31 (Suppl. 4), S238-S242. [CrossRef]

79. Levi, M.; Levy, J.H.; Andersen, H.F.; Truloff, D. Safety of recombinant activated factor VII in randomized clinical trials. N. Engl. J. Med. 2010, 363, 1791-1800. [CrossRef]

80. Stanworth, S.J.; Birchall, J.; Doree, C.J.; Hyde, C. Recombinant factor VIIa for the prevention and treatment of bleeding in patients without haemophilia. Cochrane Database Syst. Rev. 2007, CD005011. [CrossRef]

81. Park, J.A.; Kim, B.J. Intrapulmonary recombinant factor VIIa for diffuse alveolar hemorrhage in children. Pediatrics 2015, 135, e216-e220. [CrossRef] [PubMed]

82. Esper, R.C.; Estrada, I.E.; de la Torre Leon, T.; Gutierrez, A.O.; Lopez, J.A. Treatment of diffuse alveolar hemorrhage secondary to lupus erythematosus with recombinant activated factor VII administered with a jet nebulizer. J. Intensive Care $2014,2,47$. [CrossRef] [PubMed]

83. Ellery, P.E.; Adams, M.J. Tissue factor pathway inhibitor: Then and now. Semin. Thromb. Hemost. 2014, 40, 881-886. [CrossRef]

84. Wood, J.P.; Ellery, P.E.; Maroney, S.A.; Mast, A.E. Biology of tissue factor pathway inhibitor. Blood 2014, 123, 2934-2943. [CrossRef] [PubMed]

85. Kristensen, J.; Killander, A.; Hippe, E.; Helleberg, C.; Ellegard, J.; Holm, M.; Kutti, J.; Mellqvist, U.H.; Johansson, J.E.; Glazer, S.; et al. Clinical experience with recombinant factor VIIa in patients with thrombocytopenia. Haemostasis 1996, 26 (Suppl. 1), 159-164. [PubMed]

86. Al Hammadi, A.M.; Sallah, S. Efficacy and safety of recombinant factor VIIa in the treatment of bleeding episodes in patients with aplastic anemia. J. Thromb. Haemost. 2007, 5, 435-436. [CrossRef] [PubMed]

87. Farah, R.A.; Hamod, D.; Melick, N.; Giansily-Blaizot, M.; Sallah, S. Successful prophylaxis against intracranial hemorrhage using weekly administration of activated recombinant factor VII in a newborn with severe factor VII deficiency. J. Thromb. Haemost. 2007, 5, 433-434. [CrossRef]

88. Tengborn, L.; Petruson, B. A patient with Glanzmann thrombasthenia and epistaxis successfully treated with recombinant factor VIIa. Thromb. Haemost. 1996, 75, 981-982. [PubMed]

89. Kenet, G.; Walden, R.; Eldad, A.; Martinowitz, U. Treatment of traumatic bleeding with recombinant factor VIIa. Lancet 1999, 354, 1879. [CrossRef]

90. Pihusch, M.; Bacigalupo, A.; Szer, J.; von Depka Prondzinski, M.; Gaspar-Blaudschun, B.; Hyveled, L.; Brenner, B. Recombinant activated factor VII in treatment of bleeding complications following hematopoietic stem cell transplantation. J. Thromb. Haemost. 2005, 3, 1935-1944. [CrossRef]

91. Yadav, S.P.; Sachdeva, A.; Bhat, S.; Katewa, S. Successful control of massive gastrointestinal bleeding following umbilical cord blood transplantation (UCBT) by use of recombinant activated factor VII (rFVIIa) and octreotide infusion. Pediatr. Hematol. Oncol. 2010, 27, 24-30. [CrossRef] [PubMed]

92. Harkensee, C.; Vasdev, N.; Gennery, A.R.; Willetts, I.E.; Taylor, C. Prevention and management of BK-virus associated haemorrhagic cystitis in children following haematopoietic stem cell transplantation-a systematic review and evidence-based guidance for clinical management. Br. J. Haematol. 2008, 142, 717-731. [CrossRef] [PubMed]

93. Simpson, E.; Lin, Y.; Stanworth, S.; Birchall, J.; Doree, C.; Hyde, C. Recombinant factor VIIa for the prevention and treatment of bleeding in patients without haemophilia. Cochrane Database Syst. Rev. 2012, CD005011. [CrossRef]

94. Brady, K.M.; Easley, R.B.; Tobias, J.D. Recombinant activated factor VII (rFVIIa) treatment in infants with hemorrhage. Paediatr. Anaesth. 2006, 16, 1042-1046. [CrossRef]

95. Bhat, S.; Yadav, S.P.; Anjan, M.; Dinand, V.; Sachdeva, A. Recombinant activated factor VII usage in life threatening hemorrhage: A pediatric experience. Indian J. Pediatr. 2011, 78, 961-968. [CrossRef] [PubMed]

96. Elinoff, J.M.; Bagci, U.; Moriyama, B.; Dreiling, J.L.; Foster, B.; Gormley, N.J.; Salit, R.B.; Cai, R.; Sun, J.; Beri, A.; et al. Recombinant human factor VIIa for alveolar hemorrhage following allogeneic stem cell transplantation. Biol. Blood Marrow Transplant. 2014, 20, 969-978. [CrossRef] [PubMed]

97. Dabar, G.; Harmouche, C.; Jammal, M. Efficacy of recombinant activated factor VII in diffuse alveolar haemorrhage. Rev. Mal. Respir. 2011, 28, 106-111. [CrossRef] [PubMed]

98. Estella, A.; Jareno, A.; Perez-Bello Fontaina, L. Intrapulmonary administration of recombinant activated factor VII in diffuse alveolar haemorrhage: A report of two case stories. Cases J. 2008, 1, 150. [CrossRef]

99. Mandal, S.K.; Sagar, G.; Sahoo, M.; Jasuja, S. Recombinant activated factor VII for diffuse alveolar hemorrhage in microscopic polyangiitis. Indian J. Nephrol. 2012, 22, 130-132.

100. Alabed, I.B. Treatment of diffuse alveolar hemorrhage in systemic lupus erythematosus patient with local pulmonary administration of factor VIIa (rFVIIa): A case report. Medicine 2014, 93, e72. [CrossRef]

101. Khoulani, D.; Rao, B.; Khanshour, A.; Kuriakose, P.; Yessayan, L. Failure of Recombinant Activated Factor VII in Treatment of Diffuse Alveolar Hemorrhage due to Cryoglobulinemic Vasculitis. Case Rep. Hematol. 2014, 2014, 283086. [CrossRef] [PubMed]

102. Pathak, V.; Kuhn, J.; Gabriel, D.; Barrow, J.; Jennette, J.C.; Henke, D.C. Use of Activated Factor VII in Patients with Diffuse Alveolar Hemorrhage: A 10 Years Institutional Experience. Lung 2015, 193, 375-379. [CrossRef] [PubMed]

103. Diaz, R.; Almeida, P.; Alvarez, M.; Ferrer, G.; Hernandez, F. Life-Threatening Pulmonary Hemorrhage Responds to Recombinant Factor VIIa: A Case Series in South Florida Hospitals. Cureus 2019, 11, e6202. [CrossRef] [PubMed] 
104. Meijer, K.; de Graaff, W.E.; Daenen, S.M.; van der Meer, J. Successful treatment of massive hemoptysis in acute leukemia with recombinant factor VIIa. Arch. Intern. Med. 2000, 160, 2216-2217. [CrossRef]

105. White, B.; Martin, M.; Kelleher, S.; Browne, P.; McCann, S.R.; Smith, O.P. Successful use of recombinant FVIIa (Novoseven) in the management of pulmonary haemorrhage secondary to Aspergillus infection in a patient with leukaemia and acquired FVII deficiency. Br. J. Haematol. 1999, 106, 254-255. [CrossRef]

106. Hicks, K.; Peng, D.; Gajewski, J.L. Treatment of diffuse alveolar hemorrhage after allogeneic bone marrow transplant with recombinant factor VIIa. Bone Marrow Transplant. 2002, 30, 975-978. [CrossRef]

107. Yildirim, H.; Ucgun, I.; Yalcin, A.U.; Gulbas, Z.; Sahin, G.; Acikalin, M.F.; Metintas, M.; Ak, G. Recombinant factor VIIa treatment for life-threatening haemoptysis. Respirology 2006, 11, 652-654. [CrossRef]

108. Macdonald, J.A.; Fraser, J.F.; Foot, C.L.; Tran, K. Successful use of recombinant factor VII in massive hemoptysis due to community-acquired pneumonia. Chest 2006, 130, 577-579. [CrossRef]

109. Shenoy, A.; Savani, B.N.; Barrett, A.J. Recombinant factor VIIa to treat diffuse alveolar hemorrhage following allogeneic stem cell transplantation. Biol. Blood Marrow Transplant. 2007, 13, 622-623. [CrossRef]

110. Gupta, S.; Jain, A.; Warneke, C.L.; Gupta, A.; Shannon, V.R.; Morice, R.C.; Onn, A.; Jimenez, C.A.; Bashoura, L.; Giralt, S.A.; et al. Outcome of alveolar hemorrhage in hematopoietic stem cell transplant recipients. Bone Marrow Transplant. 2007, 40, 71-78. [CrossRef]

111. Lau, E.M.T.; Yozghatlian, V.; Kosky, C.; Moriarty, C.; Dentice, R.; Waugh, R.; Torzillo, P.J.; Bye, P.T. Recombinant activated factor VII for massive hemoptysis in patients with cystic fibrosis. Chest 2009, 136, 277-281. [CrossRef] [PubMed]

112. Tatopoulos, A.; Herbain, D.; Kazmierczak, C.; Bollaert, P.E.; Gibot, S. Parenteral use of recombinant activated factor VII during diffuse alveolar hemorrhage secondary to leptospirosis. Intensive Care Med. 2010, 36, 555-556. [CrossRef] [PubMed]

113. Shimizu, Y.; Tsuchiya, K.; Fujisawa, N. Risk factors of diffuse alveolar hemorrhage after acute ischemic stroke treated with tissue-type plasminogen activator. The effectiveness of activated recombinant factor VII treatment. Surg. Neurol. Int. 2020, 11, 129. [CrossRef] [PubMed]

114. Witmer, C.M.; Huang, Y.S.; Lynch, K.; Raffini, L.J.; Shah, S.S. Off-label recombinant factor VIIa use and thrombosis in children: A multi-center cohort study. J. Pediatr. 2011, 158, 820-825.e1. [CrossRef]

115. McQuilten, Z.K.; Barnes, C.; Zatta, A.; Phillips, L.E. Off-label use of recombinant factor VIIa in pediatric patients. Pediatrics 2012, 129, e1533-e1540. [CrossRef]

116. MacLaren, R.; Weber, L.A.; Brake, H.; Gardner, M.A.; Tanzi, M. A multicenter assessment of recombinant factor VIIa off-label usage: Clinical experiences and associated outcomes. Transfusion 2005, 45, 1434-1442. [CrossRef]

117. O'Connell, K.A.; Wood, J.J.; Wise, R.P.; Lozier, J.N.; Braun, M.M. Thromboembolic adverse events after use of recombinant human coagulation factor VIIa. JAMA 2006, 295, 293-298. [CrossRef]

118. Young, G.; Wicklund, B.; Neff, P.; Johnson, C.; Nugent, D.J. Off-label use of rFVIIa in children with excessive bleeding: A consecutive study of 153 off-label uses in 139 children. Pediatr. Blood Cancer 2009, 53, 179-183. [CrossRef]

119. Fekete, M.; Nemeth, A. Neonatal pulmonary haemorrhage, birthweight, gestational age and intrauterine growth. Acta Paediatr. Hung. 1985, 26, 65-73. [PubMed]

120. Larcombe, P.J.; Kapur, N.; Fraser, C.J.; Coulthard, M.G.; Schlapbach, L.J. Intrabronchial administration of activated recombinant factor VII in a young child with diffuse alveolar hemorrhage. Pediatr. Blood Cancer 2014, 61, 570-571. [CrossRef] [PubMed]

121. Veldman, A.; Fischer, D.; Voigt, B.; Beyer, P.A.; Schlosser, R.; Allendorf, A.; Kreuz, W. Life-threatening hemorrhage in neonates: Management with recombinant activated factor VII. Intensive Care Med. 2002, 28, 1635-1637. [CrossRef] [PubMed]

122. Olomu, N.; Kulkarni, R.; Manco-Johnson, M. Treatment of severe pulmonary hemorrhage with activated recombinant factor VII (rFVIIa) in very low birth weight infants. J. Perinatol. 2002, 22, 672-674. [CrossRef] [PubMed]

123. Leibovitch, L.; Kenet, G.; Mazor, K.; Matok, I.; Vardi, A.; Barzilay, Z.; Paret, G. Recombinant activated factor VII for life-threatening pulmonary hemorrhage after pediatric cardiac surgery. Pediatr. Crit. Care Med. 2003, 4, 444-446. [CrossRef] [PubMed]

124. Blatt, J.; Gold, S.H.; Wiley, J.M.; Monahan, P.E.; Cooper, H.C.; Harvey, D. Off-label use of recombinant factor VIIa in patients following bone marrow transplantation. Bone Marrow Transplant. 2001, 28, 405-407. [CrossRef] [PubMed]

125. Grizelj, R.; Vukovic, J.; Filipovic-Grcic, B.; Saric, D.; Luetic, T. Successful use of recombinant activated FVII and aminocaproic acid in four neonates with life-threatening hemorrhage. Blood Coagul. Fibrinolysis 2006, 17, 413-415. [CrossRef] [PubMed]

126. Colin, A.A.; Shafieian, M.; Andreansky, M. Bronchoscopic instillation of activated recombinant factor VII to treat diffuse alveolar hemorrhage in a child. Pediatr. Pulmonol. 2010, 45, 411. [CrossRef] 